\title{
Article \\ New Mutations in HFE2 and TFR2 Genes Causing Non HFE-Related Hereditary Hemochromatosis
}

\author{
Gonzalo Hernández ${ }^{1,2}$, Xenia Ferrer-Cortès ${ }^{1,2}$, Veronica Venturi ${ }^{1}$, Melina Musri ${ }^{2}$, Martin Floor Pilquil ${ }^{3,4}$, \\ Pau Marc Muñoz Torres ${ }^{3}$, Ines Hernandez Rodríguez ${ }^{5}$, Maria Àngels Ruiz Mínguez ${ }^{6}$, Nicholas J. Kelleher ${ }^{7}$, \\ Sara Pelucchi ${ }^{8}{ }^{-0}$, Alberto Piperno ${ }^{8,9,10}$, Esther Plensa Alberca ${ }^{11}$, Georgina Gener Ricós ${ }^{11}$, Eloi Cañamero Giró ${ }^{11}$, \\ Santiago Pérez-Montero ${ }^{2}$, Cristian Tornador ${ }^{2}$, Jordi Villà-Freixa ${ }^{3,4}$ and Mayka Sánchez ${ }^{1,2, *(1)}$
}

1 Iron Metabolism: Regulation and Diseases Group, Department of Basic Sciences,

Universitat Internacional de Catalunya (UIC), 08195 Sant Cugat del Vallès, Spain; ghernandezv@uic.es (G.H.); xferrerc@uic.es (X.F.-C.); vventuri@uic.es (V.V.)

2 BloodGenetics S.L., Diagnostics in Inherited Blood Diseases, 08950 Esplugues de Llobregat, Spain; mmusri@bloodgenetics.com (M.M.); sperez@bloodgenetics.com (S.P.-M.);

Ctornador@bloodgenetics.com (C.T.)

3 Department of Basic Sciences, Faculty of Medicine and Health Sciences, Universitat Internacional de Catalunya, 08195 Sant Cugat del Vallès, Spain; mfloor@uic.cat (M.F.P.); pmunoz@uic.es (P.M.M.T.); jordi.villa@uvic.cat (J.V.-F.)

4 Department of Biosciences, Faculty of Sciences and Technology, Universitat de Vic-Universitat Central de Catalunya, 08500 Vic, Spain

check for updates

Citation: Hernández, G.; Ferrer-Cortès, X.; Venturi, V.; Musri, M.; Pilquil, M.F.; Torres, P.M.M.; Rodríguez, I.H.; Mínguez, M.À.R.; Kelleher, N.J.; Pelucchi, S.; et al. New Mutations in HFE2 and TFR2 Genes Causing Non HFE-Related Hereditary Hemochromatosis. Genes 2021, 12, 1980. https://doi.org/10.3390/ genes12121980

Academic Editor: Sergi Puig

Received: 25 October 2021

Accepted: 8 December 2021

Published: 13 December 2021

Publisher's Note: MDPI stays neutral with regard to jurisdictional claims in published maps and institutional affiliations.

Copyright: (c) 2021 by the authors. Licensee MDPI, Basel, Switzerland. This article is an open access article distributed under the terms and conditions of the Creative Commons Attribution (CC BY) license (https:/ / creativecommons.org/licenses/by/ $4.0 /)$.
5 Hospital Germans Trias i Pujol, 08916 Badalona, Spain; agnesrh@iconcologia.net

6 Department of Laboratory Medicine/Fundació Hospital de l'Esperit Sant, 08923 Santa Coloma de Gramenet, Spain; aruiz@fhes.cat

7 Hematologia Clinica, Institut Català d'Oncologia, 17007 Girona, Spain; nkelleher@iconcologia.net

8 Department of Medicine and Surgery, University of Milano-Bicocca, 20126 Monza, Italy; sara.pelucchi@unimib.it (S.P.); alberto.piperno@unimib.it (A.P.)

9 Medical Genetics-ASST-Monza, S. Gerardo Hospital, 20900 Monza, Italy

10 Centre for Rare Diseases-Disorders of Iron Metabolism-ASST-Monza, San Gerardo Hospital, 20900 Monza, Italy

11 Hematologia i Hemoteràpia, Consorci Sanitari del Maresme, Institut Català d'Oncologia, 08304 Mataró, Spain; mplensa@csdm.cat (E.P.A.); ggener@iconcologia.net (G.G.R.); eloi.canamero@gmail.com (E.C.G.)

* Correspondence: msanchezfe@uic.es

Abstract: Hereditary hemochromatosis $(\mathrm{HH})$ is an iron metabolism disease clinically characterized by excessive iron deposition in parenchymal organs such as liver, heart, pancreas, and joints. It is caused by mutations in at least five different genes. HFE hemochromatosis is the most common type of hemochromatosis, while non-HFE related hemochromatosis are rare cases. Here, we describe six new patients of non-HFE related $\mathrm{HH}$ from five different families. Two families (Family 1 and 2) have novel nonsense mutations in the HFE2 gene have novel nonsense mutations (p.Arg63Ter and Asp36ThrfsTer96). Three families have mutations in the TFR2 gene, one case has one previously unreported mutation (Family A-p.Asp680Tyr) and two cases have known pathogenic mutations (Family B and D-p.Trp781Ter and p.Gln672Ter respectively). Clinical, biochemical, and genetic data are discussed in all these cases. These rare cases of non-HFE related hereditary hemochromatosis highlight the importance of an earlier molecular diagnosis in a specialized center to prevent serious clinical complications.

Keywords: HFE related hereditary hemochromatosis; non-HFE related hereditary hemochromatosis; iron overload; missense; nonsense; homozygous; TFR2 gene; HFE2 gene

\section{Introduction}

Iron is a bio-mineral and a micronutrient with a key role in a wide range of cellular processes such as erythropoiesis, oxygen transport (as a critical component of hemoglobin), 
DNA synthesis or energy production. Since both low and high levels of iron are linked to life threatening complications [1], a complex system of proteins and gene regulation exists to keep iron levels in a safe range and to ensure all the iron-related processes working in optimal conditions. A key regulator of iron metabolism is the hepcidin peptide, the liverproduced iron regulatory hormone coded by the HAMP gene [2]. In healthy individuals (Figure 1, left panel), with adequate iron levels in hepatocytes, hepcidin expression is induced by a signaling cascade in which participates several proteins. One of the events in this cascade is the binding of the transferrin protein (TF) with the Transferrin Receptor 1 (TFR1) protein (responsible for the cellular iron uptake) and, with a much-reduced affinity, to the Transferrin Receptor 2 (TFR2) protein (responsible for the iron levels sensing). TFR2, encoded by the TFR2 gene, is a TFR1-homologue protein that exists as a transmembrane homodimer being mainly expressed in the liver [3] and in bone marrow erythroblasts, where it regulates the activity of the EPO receptor to adapt the production of RBC to the available amount of iron-bound TF [4]. The TF-TFR1 binding displaces the HFE protein that then is free to interact with TFR2 to generate the signal required for hepcidin production. In addition, the Bone Morphogenic Protein (BMP) cytokines BMP2 and BMP6, secreted by the liver sinusoidal endothelial cells (LSECs), interact with the BMP receptors 1 and 2 and the BMP co-receptor HJV protein (a GPI-linked protein encoded by the HFE2 gene), to also signal for hepcidin production [5]. The BMPR-HJV cascade can be inhibited by the action of the matriptase-2 protein (encoded by the TMPRSS6 gene). Both signaling events (HFETFR2 and HJV-BMPR) trigger the phosphorylation of the SMAD1/5/8 proteins forming a complex with SMAD4 that will translocate to the nucleus and induce the expression of the HAMP gene. The hepcidin produced is secreted to the blood stream and will inhibit (by inducing its degradation) the FPN protein, an iron pump that is responsible for the iron absorption in the duodenum and iron release from macrophages. By reducing the FPN levels, hepcidin reduces the iron availability from dietary iron absorption and iron secretion by reticuloendothelial system (RES) macrophages. The relevant function of all these proteins in iron homeostasis has been revealed by the generation on knock-out mouse models that phenocopy the human HFE and non-HFE related hereditary hemochromatosis disease [6-11].

Alterations in this signaling cascade leads to reduced production of hepcidin and to the manifestations of the different forms of hereditary hemochromatosis $(\mathrm{HH})$ [12]. This reduction in hepcidin production (Figure 1, right panel) results in an excessive iron absorption that eventually accumulates in organs such as liver, heart, joints and pancreas [13]. The iron accumulation in those organs over time produces tissue damage and other clinical manifestations such as cirrhosis, diabetes mellitus, arthropathy, cardiomyopathy, hypogonadism, impotence, and hepatocellular carcinoma. To avoid organ damage, it is vital an early diagnose and early implementation of iron chelation or iron reduction treatment to diminish iron overload.

$\mathrm{HH}$ has been traditionally subdivided into four different types associated with mutations in five different genes involved, as seen before, in hepcidin regulation. Type 1 is the most common form of HH (OMIM \#235200), and it is linked to mutations in the major histocompatibility complex class I-like protein encoded by the HFE gene (OMIM *613609) [14]. Juvenile hemochromatosis is the name of the HH types 2a and 2b (OMIM $\# 602390$ and \#613313) that are caused by mutations in the hemojuvelin (HJV) protein (coded by the HFE2 gene) and in the iron hormone hepcidin (coded by the HAMP gene) (OMIM *608374 and *606464) [2,15]. Type $3 \mathrm{HH}$ (OMIM \#604250) is associated with genetic alterations in the Transferrin receptor 2 (TFR2) gene (OMIM *604720) [16]. Type 3 HH was originally considered to be a disease with an adult onset; however, there are reports of patients with a juvenile onset of this disease [17-19]. In type 4b HH (OMIM \#606069), there are gain-of-function mutations in the iron exporter ferroportin (FPN) protein (coded by the SLC40A1 gene) (OMIM *604653) [20]. In general, $\mathrm{HH}$ is mainly an autosomal recessive disease except for the $\mathrm{HH}$ type $4 \mathrm{~b}$ caused by dominant mutations in the SLC40A1 gene. 
Clinically, $\mathrm{HH}$ types $2 \mathrm{a}, 2 \mathrm{~b}$ and 3 present with more severe and earlier iron overload complications compared with type 1 and $4 \mathrm{~b}$.

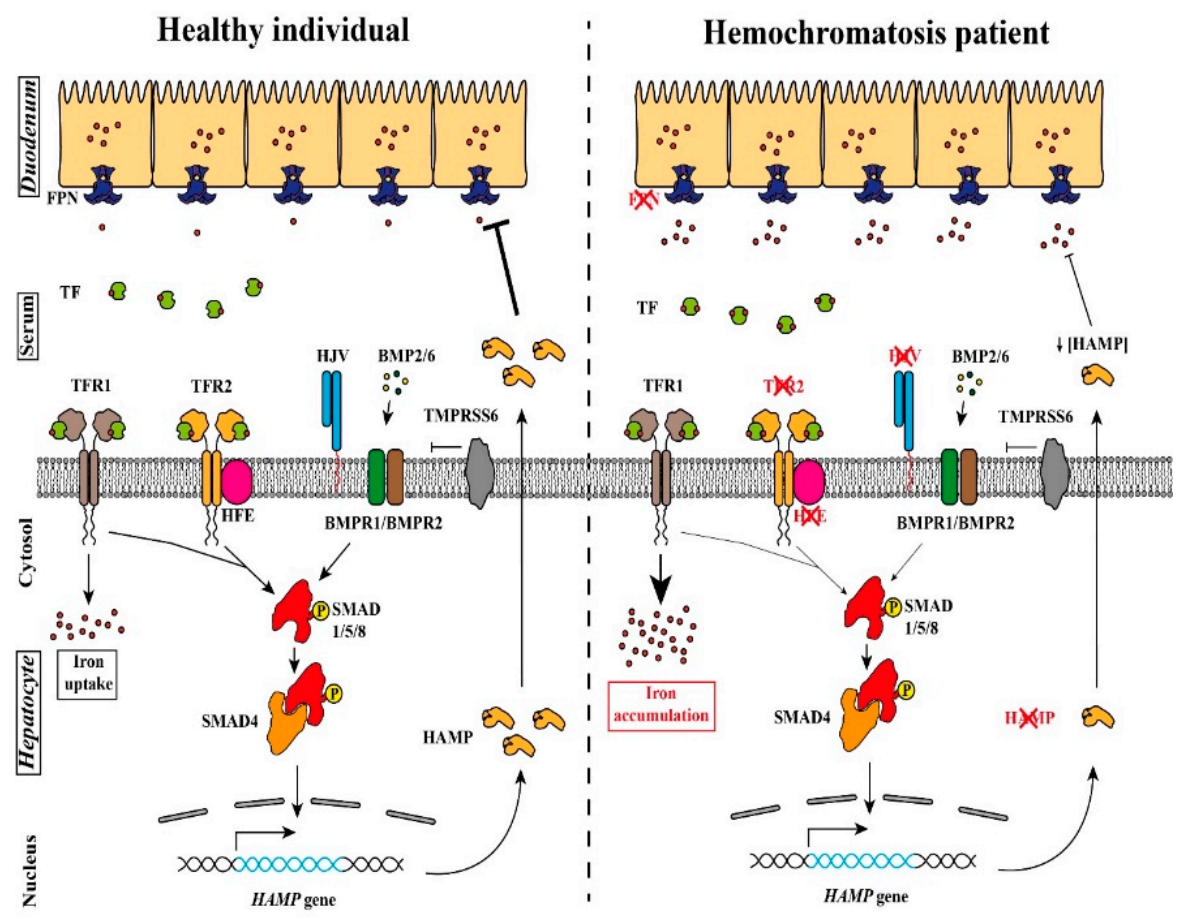

Figure 1. Model for the hepcidin expression and its alterations in hereditary hemochromatosis (HH). Left, the coordinated signaling of the TFR1, TFR2, HFE, HJV and BMP receptors activated the SMAD complex that promotes HAMP expression. The hepcidin produced is then released to the blood stream and will stimulate the FPN degradation in the duodenum epithelial cells, limiting iron absorption. Right, in an individual affected by $\mathrm{HH}$, mutations in any of the proteins marked with a red cross result in a reduction in the serum hepcidin levels. This leads to an uncontrolled iron absorption by the duodenum that will result in an iron accumulation in the tissues.

Recently, a new classification for HH has been proposed, where the previously described types of $\mathrm{HH}$ have been reorganized into the "HFE-related" $\mathrm{HH}$ caused by mutations in the HFE gene, the "non HFE-related" due to mutations in the HFE2, HAMP, TFR2 and gain-of-function mutations in the SLC40A1 gene, the "Digenic" caused by compound heterozygosity between mutations in iron-metabolism-related genes (HFE and/or non-HFE genes) and lastly, the "molecularly undefined" group where the genetic origin is unknown. From this point forward, we will use this new recommended nomenclature [21].

$\mathrm{Up}$ to date, 98 patients from 87 different families with non-HFE related $\mathrm{HH}$ due to pathogenic mutations in the HFE2 gene have been described in the literature (Table A1) [22,23]. As we can see in Figure 2, the mutations are scattered across the length of the HJV protein, with no evident clustering. 


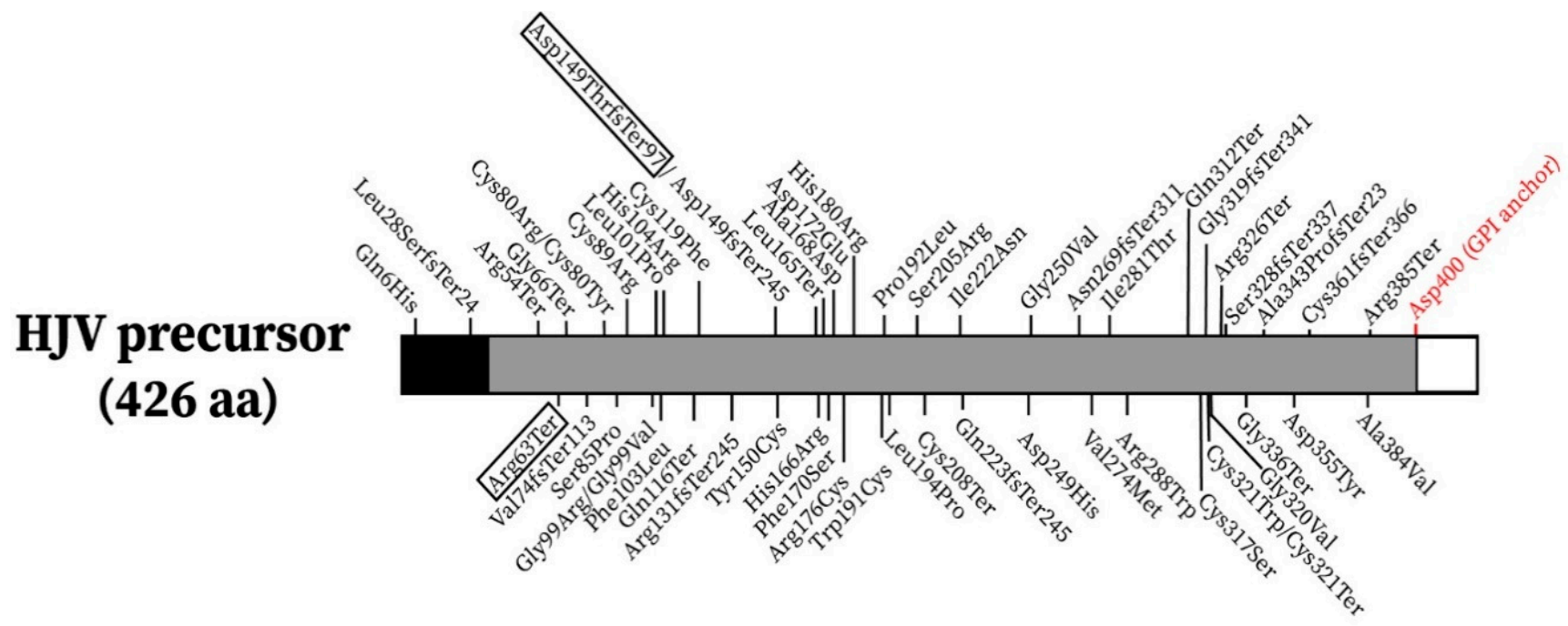

Figure 2. Localization of the reported pathogenic mutations in the HJV precursor. The new mutations reported in this work are boxed. The black region in the $\mathrm{N}$-terminal represents the signal peptide while the white box at the C-terminal represents a portion that will be removed in the maturation process, exposing the Asp400 residue (in red) necessary for the GPI anchor of the HJV protein to the membrane.

Up to date, a total of 45 families (66 affected patients) with non-HFE related $\mathrm{HH}$ due to pathogenic mutations in the TFR2 gene have been described in the literature (Table A2) [24,25]. It has been shown that in a hepatic murine system (Hepa1-6 cells), the murine counterparts of four human TFR2 mutations (Met172Lys, AVAQ621_624del, Gln690Pro and Tyr250Ter) cause intracellular retention of the protein at the endoplasmic reticulum [26]. As in HJV, TFR2 mutations are scattered along the protein (Figure 3).

Here, we describe six patients with non-HFE related HH from five unrelated families and two previously unreported mutations in the HFE2 gene and two novel mutations in the TFR2 gene. 


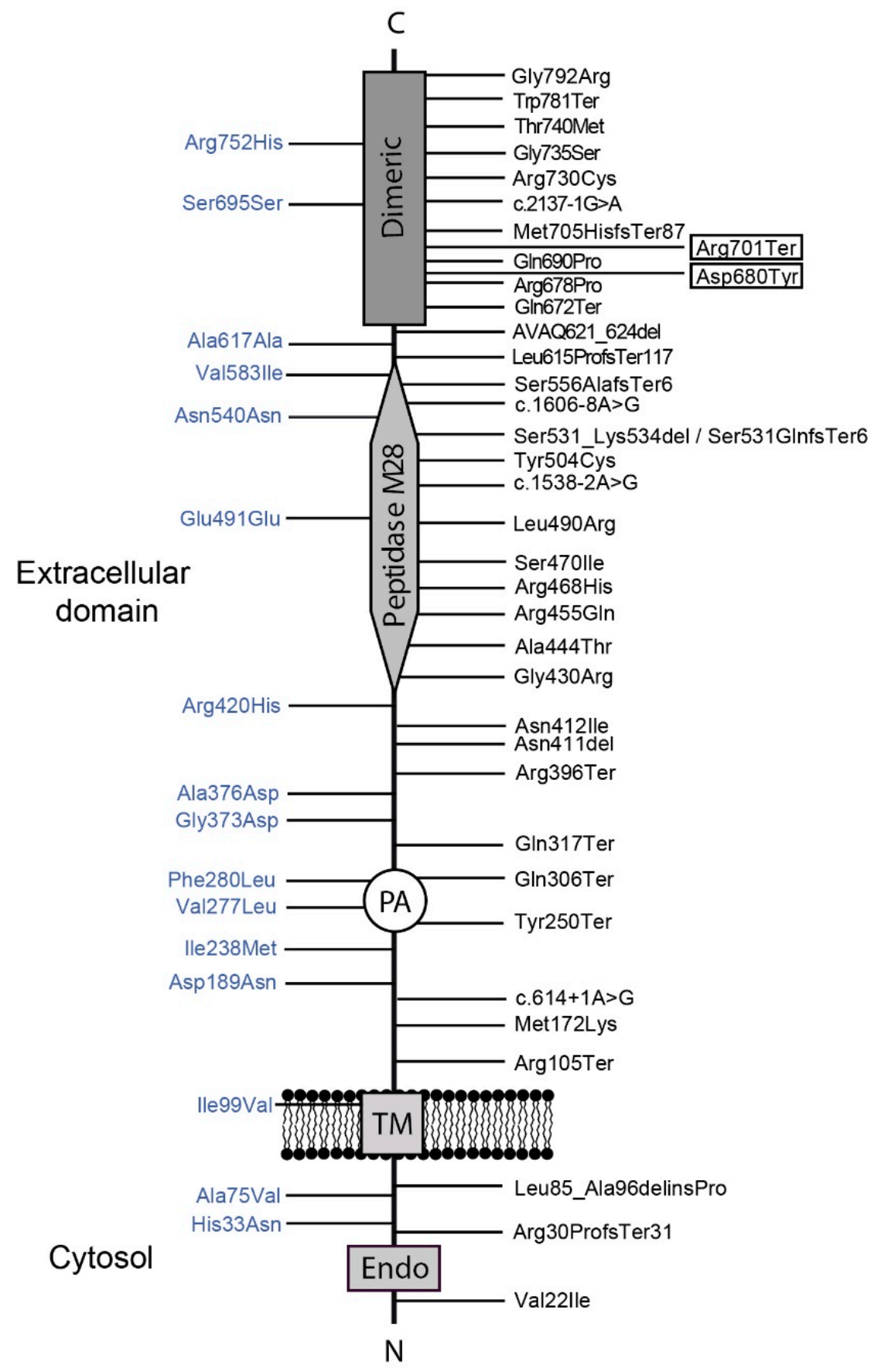

TM: transmembrane domain

PA: protease-associated domain

Dimeric: transferrin receptor-like dimerization region

Figure 3. Localization of the reported mutations in the TFR2 protein. The new mutations reported are boxed. Dimeric, Transferrin Receptor-like dimerization region; TM, transmembrane domain; $P A$, Protease-Associated domain. Image adapted from Joshi et al. [23].

\section{Materials and Methods}

\subsection{Patients}

2.1.1. Non-HFE HH Related Due to Mutations in the HFE2 Gene: Family 1

Patient 1.II.1 (Figure $4 \mathrm{a}$ left) is a male diagnosed at the age of 37. Biochemical data revealed mild basal fasting hyperglycemia with mild insulin resistance (HOMA index of 3.7), vitamin D and folic acid deficit and hypogonadotropic hypogonadism. Hepatic 
ultrasound showed a slightly increased liver with irregular structure, elastography revealed liver fibrosis and magnetic resonance shows severe liver [T2* $1 \mathrm{~ms}$, corresponding to a liver iron concentration (LIC) of $457 \mu \mathrm{mol} / \mathrm{g}$ dry weight [27] and cardiac (T2*9 ms) iron overload. Liver biopsy showed cirrhosis and marked iron overload (Figure A1). Despite cardiac overload, echocardiography showed normal morphology and ventricular function with ground glass aspect of the medio-basal ventricular septum. This indicates that $\mathrm{T}^{*}$ was identifying preclinical iron deposition as previously observed in patients with transfusion-dependent thalassemia with cardiac iron overload [28,29]. Because of the severe iron overload, the patient underwent to combined therapy to remove as soon as possible the systemic iron burden. Based on previous experience, we opted for erythroapheresis to maintain isovolemia (considering the cardiac iron overload) plus recombinant erythropoietin administration ( $8000 \mathrm{UI} /$ week for three weeks/month) to maximize the efficacy of erythroapheresis [30]. In addition, subcutaneous deferoxamine infusion $(1 \mathrm{~g}$ twice/day for 5 days/week) was used. Iron depletion was achieved after the removal of $15 \mathrm{~g}$ of iron in one year. Afterward, phlebotomy therapy every 3-4 months was performed, maintaining ferritin levels around $50 \mathrm{ng} / \mathrm{mL}$.

\subsubsection{Non-HFE HH Related Due to Mutations in the HFE2 Gene: Family 2}

Patient 2.II.1 (Figure 4a right) is a male diagnosed at the age of 34 years old. He presented with high serum ferritin levels (but $<1000 \mu \mathrm{g} / \mathrm{L}$ ) and high serum iron. In addition, he had hypogonadotropic hypogonadism treated with testosterone and moderate hepatic steatosis. As expected for an iron overload disease, the hepcidin levels of the patient were low $(0.1919 \mathrm{ng} / \mathrm{mL})$. One year later, serum ferritin levels peaked to $3942 \mu \mathrm{g} / \mathrm{L}$. Magnetic resonance shows no evidence of iron overload in the heart while in the liver revealed increased iron concentration of $47 \mu \mathrm{mol} / \mathrm{g}$ indicative of hepatic iron overload (normal values $<36 \mu \mathrm{mol} / \mathrm{g}$ ). Iron chelation with Desferoxamine was used as the main therapeutic treatment. Initially, phlebotomies were performed in combination with iron chelation but had to be stopped due to intolerance. Iron chelation treatment ended in 2020 and the patient is now asymptomatic. The patient will continue with maintenance therapy.

\subsubsection{Non-HFE HH Related Due to Mutations in the TFR2 Gene: Family A}

Patients A.II.1 and A.II.2 (Figure 4b upper first panel) are two male brothers of Asian origin diagnosed with $\mathrm{HH}$ at 35 and 37 years old respectively. Both presented with high levels of serum ferritin and iron, while in both patients, the hepcidin levels were 0.2395 and $0.0111 \mathrm{ng} / \mathrm{mL}$ respectively. Hepatic magnetic resonance showed a severe hepatic iron overload $(282.97 \mu \mathrm{mol} \mathrm{Fe} / \mathrm{g}$ and $265 \mu \mathrm{mol} \mathrm{Fe} / \mathrm{g})$. The treatment option for both patients consisted of weekly phlebotomies in combination with iron chelation (Desferoxamine). A.II.1 proband started the phlebotomies in January 2019 (weekly) and the Desferoxamine treatment in May 2019. In February 2021, after 100 phlebotomies and approximately $22 \mathrm{~g}$ of iron removal the ferritin levels dropped to normal levels, but transferrin saturation remained high. A.II.2 proband started the phlebotomies in July 2017 (once a month) and the Desferoxamine treatment in January 2018 (initial dose of $1080 \mathrm{mg}$ /day that eventually was increased to $2160 \mathrm{mg}$ /day in May 2018). At the last data available (February 2021), the patient accumulated a total of 46 phlebotomies that removed a total amount of $9 \mathrm{~g}$ of iron and resulted in the normalization of ferritin and transferrin saturation parameters. The iron depletion was partially confirmed by the last hepatic magnetic resonance performed to the A.II.2 patient that showed a moderate iron overload $(70.33 \mu \mathrm{mol} \mathrm{Fe} / \mathrm{g})$. 
a)

Family 1

I

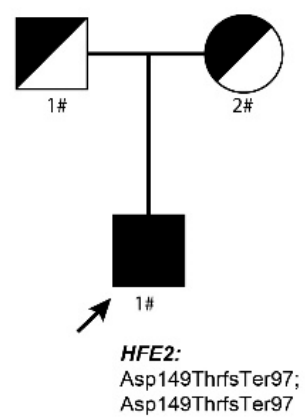

Family 2

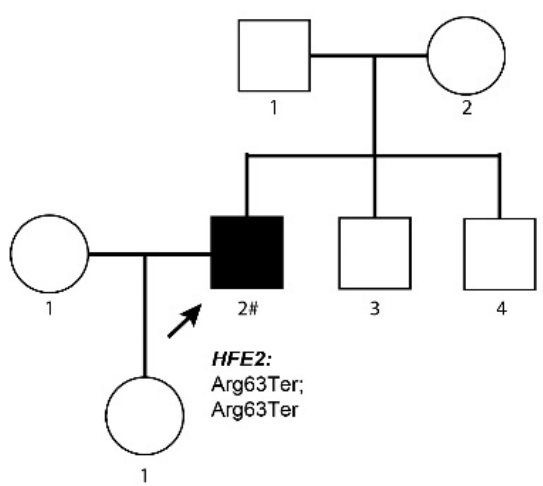

b)

\section{Family A}

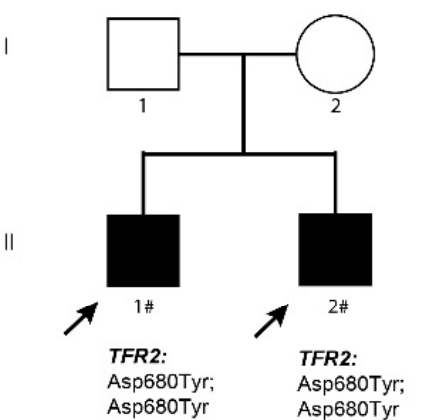

Family B

I

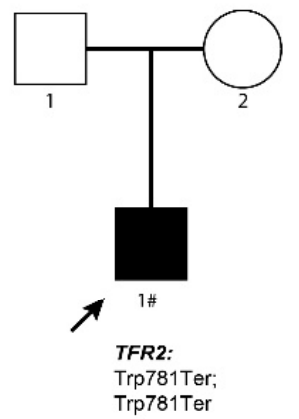

Family C

I

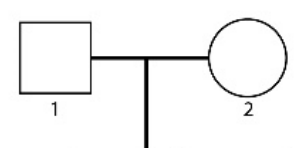

II

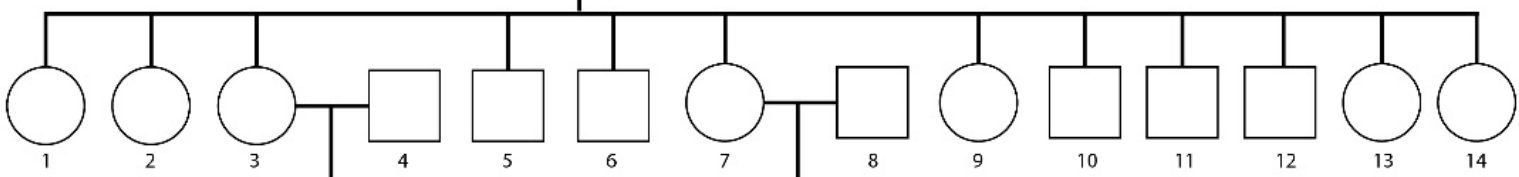

III

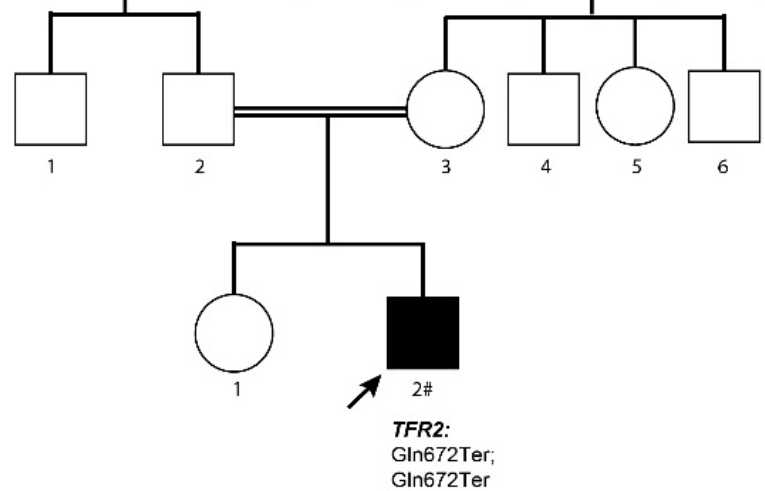

Figure 4. Non-HFE hereditary hemochromatosis families: families and mutations. The probands are indicated with an arrow. Black symbols denote affected individuals and half-filled black symbols unaffected carriers. Individuals studied at the molecular level are indicated with the \# symbol. (a) Pedigrees of the two non-HFE related HH families carrying HFE2 mutations. (b) Pedigrees of the three non-HFE related HH families carrying TFR2 mutations. 


\subsubsection{Non-HFE HH Related Due to Mutations in the TFR2 Gene: Family B}

Patient B.II.1 (Figure $4 \mathrm{~b}$ upper second panel) is a male of 46 years old diagnosed in 2012 with hemochromatosis that presented with hyperferritinemia and severe hepatic iron accumulation $(300 \mu \mathrm{mol} \mathrm{Fe} / \mathrm{g})$ detected by hepatic magnetic resonance. The patient also suffers from dyslipidemia and internal hemorrhoids. The patient does not consume alcohol and is an ex-smoker as of May 2014. Genetic analysis shows that this patient is a carrier for the Cys282Tyr mutation in the HFE gene. Secondary to the hemochromatosis, the patient presents with severe chronic arthropathy in feet, spine (spondylarthrosis) and hands. The treatment initially was monthly erythroapheresis (later, the rate of erythroapheresis was reduced to once every two months). In January 2015, phlebotomies were introduced as part of the treatment. In May 2017, the hepatic magnetic resonance showed no sign of hepatic iron overload.

\subsubsection{Non-HFE HH Related Due to Mutations in the TFR2 Gene: Family C}

Patient C.II.1 (Figure $4 \mathrm{~b}$ bottom panel) is a male diagnosed at age 25 whose parents are consanguineous (first cousins). He presented with high serum ferritin and high transferrin saturation compatible with $\mathrm{HH}$. The hepatic magnetic resonance showed iron overload $(123.9 \mu \mathrm{mol} \mathrm{Fe} / \mathrm{g})$. In February 2021, phlebotomies were started at a rate of once a week. After 12 rounds of phlebotomies (April 2021), the ferritin levels and transferrin saturation dropped to $377 \mathrm{ng} / \mathrm{mL}$ and $13.9 \%$ respectively. At this point, the frequency of phlebotomies was reduced to once a month. At the last control (July 2021), the ferritin and saturation dropped to normal levels ( $16 \mathrm{ng} / \mathrm{mL}$ and $4.8 \%$ respectively). Currently, the phlebotomies have been stopped. Iron depletion was reached after 15 rounds of phlebotomies that removed approximately $3 \mathrm{~g}$ of iron. Both proband and its sister also suffer from sensorineural hearing loss.

\subsection{DNA Sequencing and Analysis}

Patients were diagnosed using a targeted NGS gene panel (v16) for HH (BloodGenetics \#10010 panel) including the following known genes involved in Hereditary Hemochromatosis: BMP6, FTH1, FTL, GNPAT, HAMP, HFE, HFE2, PIGA, TFR2 and SLC40A1 and methodologically as reported previously by Vila-Cuenca [31]. Variants were validated by conventional Sanger. Data analysis was performed using VarSome clinical software [32]. The CADD score was calculated using the web server (https:/ / cadd.gs.washington.edu/snv accessed on 15 September 2021). Reported mutations in this study have been submitted to ClinVar (http:/ / www.ncbi.nlm.nih.gov/ clinvar, accessed on 1 December 2021).

\subsection{Hepcidin Determination}

Hepcidin concentrations in patients' plasma/serum samples were quantified by competition enzyme-linked immunoassay (C-ELISA) using the hepcidin-25 (human) enzyme immunoassay kit (DRG) according to the manufacturer's protocol. Samples and standards were run in duplicate. Hepcidin concentrations were interpolated from standard curves generated by a four-parameter logistic nonlinear regression model using Prism (GraphPad Software Inc., La Jolla, CA, USA).

\subsection{Computational Studies}

2.4.1. Computational Model of TFR2 and TFR2/TF Based on Comparative Modeling with TFR1 Crystal Structure

The human TFR2 sequence was obtained from the UniProt database with ID Q9UP52. Using the available crystal structures for the TFR1 protein (PDB IDs: 1CX8, 1DE4, 1SUV, 2NSU, 3KAS, 3S9L, 3S9M, 3S9N, 6D03, 6D04, 6D05, 6OKD, 6W3H, and 6Y76), one thousand comparative models were generated for the TFR2 protein using the Modeller program [33]. The structures were further clustered into one hundred RMSD clusters and were subsequently docked to the TF protein based on the available complex of TFR1 and TF (PDB 1SUV). Each structure was optimized several times by searching the local conformational 
space using the Rosetta modeling suite [34]. The lowest energy model produced was then selected as the TFR2/TF heterodimer model. To build the dimeric model of TFR2 interacting with TF, we docked the previously obtained model with a copy of itself, based on the relative orientation of the TFR1 dimer in the 1SUV structure. The docked pose was subjected to several trajectories of full energy optimization, and the lowest energy score was selected as the final hetero-tetrameric model. The TFR2/TF D680Y mutant model was derived from the previous structure by optimizing the rotameric packing of residues surrounding position 680. Different distance thresholds were used to select which residues were allowed to repack during this optimization. Likewise, the lowest energy structure was selected as the final dimeric model.

\subsubsection{Sequence Similarity Network of TFR1 and TFR2 Orthologs}

Orthologous sequences for TFR1 and TFR2 were downloaded from the NCBI database [35]. To remove highly similar sequences, they were filtered for a maximum of $95 \%$ of sequence identity using the CD-HIT program [36]. A pairwise sequence similarity matrix was calculated among the selected protein sequences using the MAFFT program [37], and interaction edges were defined for pairwise similarities above a threshold of 59\%. The final network was calculated and depicted with the Cytoscape program using an organic layout [38]. The NCBI codes employed to build the protein sequence similarity network are available upon request.

\section{Results}

\subsection{Novel Cases of Non-HFE Related HH}

Clinical data for each case is present in the patients and methods section; probands presented high serum iron, high serum ferritin, and high transferrin saturation levels, as expected for $\mathrm{HH}$ patients, and with low hepcidin levels when available. The characteristic liver iron overload typical of $\mathrm{HH}$ was confirmed by liver MRI in the 2.II.2, A.II.1, A.II.2 and C.II.1 probands (Tables 1 and 2) or by liver biopsy (1.II.1 proband), while some of the probands presented with other $\mathrm{HH}$-associated complications such as hypogonadotropic hypogonadism, arthropathy and diabetes mellitus. Extended biochemical data is depicted in Table 1 for non-HFE patients with HFE2 mutations and Table 2 for non-HFE HH patients with TFR2 mutations.

Table 1. Clinical, biochemical, and genetic data of patients affected of autosomal recessive non-HFE related HH due to HFE2 mutations. F, female; M, male. (a) Data before iron depletion. (b) Data after iron depletion. (c) Data at first analysis. (d) Second follow-up. (e) Most recent data (May 2020). n.a., not available. * Adult serum hepcidin reference values according to (Ganz et al., 2008) are: mean of $121 \mathrm{ng} / \mathrm{mL}$ (5-95\% CI: 29-254 ng/mL) for men and mean of $87 \mathrm{ng} / \mathrm{mL}$ (5-95\% CI: 17-286 ng/mL) for women.

\begin{tabular}{|c|c|c|c|}
\hline & Family 1-Patient II.1 & Family 2-Patient II.2 & Normal Range \\
\hline$e x$ & $\mathrm{M}$ & $\mathrm{M}$ & \\
\hline Age at clinical diagnosis & 37 & 34 & \\
\hline \multirow{2}{*}{ Hemoglobin, $\mathrm{Hb}(\mathrm{g} / \mathrm{L})$} & $14.6(\mathrm{a})$ & $14.9(\mathrm{c})$ & M: 13.5-17.5 \\
\hline & $14.7(b)$ & $16.7(\mathrm{e})$ & F: 12.1-15.1 \\
\hline \multirow{2}{*}{$M C V(f l)$} & 86.5 (a) & $94.4(\mathrm{c})$ & \multirow{2}{*}{$80-95$} \\
\hline & $84(\mathrm{~b})$ & $94.4(\mathrm{e})$ & \\
\hline \multirow{2}{*}{ Serum iron $(\mu g / d L)$} & 247 (a) & $267(d)$ & \multirow{2}{*}{ 59-158 } \\
\hline & $80(b)$ & 109 (e) & \\
\hline \multirow{3}{*}{ Serum ferritin $(\mu g / L)$} & & $650(\mathrm{c})$ & \multirow{3}{*}{$\begin{array}{l}\text { M: } 12-300 \\
\text { F: } 12-200\end{array}$} \\
\hline & 4620 (a) & 3952 (d) & \\
\hline & 29 (b) & $27(\mathrm{e})$ & \\
\hline \multirow{2}{*}{ Transferrin $(m g / d L)$} & 198 (a) & $218(d)$ & \multirow{2}{*}{$220-400$} \\
\hline & 406 (b) & $313(\mathrm{e})$ & \\
\hline
\end{tabular}


Table 1. Cont.

\begin{tabular}{|c|c|c|c|}
\hline & Family 1-Patient II.1 & Family 2-Patient II.2 & Normal Range \\
\hline Transferrin Saturation (\%) & $\begin{array}{l}87(\mathrm{a}) \\
14(\mathrm{~b})\end{array}$ & $\begin{array}{l}84(d) \\
25(e)\end{array}$ & $20-50$ \\
\hline $\begin{array}{c}\text { Total Iron Binding Capacity } \\
(\mu g / d L)\end{array}$ & n.a. & $\begin{array}{l}301(\mathrm{~d}) \\
432(\mathrm{e})\end{array}$ & $250-400$ \\
\hline Hepcidin levels $(n g / m L)$ & n.a. & 0.19 & $\begin{array}{l}\text { M: } 29-254 * \\
\text { F: } 17-286 *\end{array}$ \\
\hline MRI liver & $\begin{array}{c}457 \mu \mathrm{mol} \mathrm{Fe} / \mathrm{g}(\mathrm{a}) \\
30 \mu \mathrm{mol} \mathrm{Fe} / \mathrm{g}(\mathrm{b}) \\
13 \mu \mathrm{mol} \mathrm{Fe} / \mathrm{g}(2020)\end{array}$ & $\begin{array}{l}\text { July 2019: } \\
47 \mu \mathrm{mol} \mathrm{Fe/g} \text {. }\end{array}$ & $<36 \mu \mathrm{mol} \mathrm{Fe} / \mathrm{g}$ \\
\hline MRI heart & $\begin{array}{c}9 \mathrm{~ms}(\mathrm{a}) \\
15 \mathrm{~ms}(\mathrm{~b}) \\
30 \mathrm{~ms}(2020)\end{array}$ & No iron overload & \\
\hline Treatments & $\begin{array}{l}\text { Phlebotomy (2014) } \\
\text { Erythroapheresis } \\
\text { Desferoxamine (2014) } \\
\text { rHuEPO (2014) }\end{array}$ & $\begin{array}{l}\text { Phlebotomy } \\
\text { Desferoxamine (until March } \\
\text { 2020) }\end{array}$ & \\
\hline Genetics & $\begin{array}{l}\text { HFE2: NM_213653.3: } \\
\text { c.445delG; c.445delG } \\
\text { p.Asp149ThrfsTer97; } \\
\text { p.Asp149ThrfsTer97 }\end{array}$ & $\begin{array}{c}\text { HFE2: NM_213653.3: } \\
\text { c.187C > T; c.187C > T } \\
\text { p.Arg63Ter; p.Arg63Ter }\end{array}$ & \\
\hline
\end{tabular}

Table 2. Clinical, biochemical, and genetic data of patients affected of autosomal recessive non-HFE related HH due to TFR2 mutations. F, Female. M, Male. (a) Data from January 2019. (b) Data from January 2018. (c) Data from November 2018. (d) Data from May 2019. n.a., not available. * Adult serum hepcidin reference values according to (Ganz et al., 2008) are: mean of $121 \mathrm{ng} / \mathrm{mL}$ (5-95\% CI: 29-254 ng/mL) for men and mean of $87 \mathrm{ng} / \mathrm{mL}$ (5-95\% CI: 17-286 ng/mL) for women. ${ }^{\#}$ Last available data from July 2021. ${ }^{* *}$ Last data available from February 2021. ${ }^{* * *}$ Last data available from September 2019.

\begin{tabular}{|c|c|c|c|c|c|}
\hline & $\begin{array}{l}\text { Family A- } \\
\text { Patient II.1 }\end{array}$ & $\begin{array}{l}\text { Family } A- \\
\text { Patient II.2 }\end{array}$ & $\begin{array}{l}\text { Family B- } \\
\text { Patient II.1 }\end{array}$ & $\begin{array}{c}\text { Family } \\
\text { C-Patient II.2 }\end{array}$ & Normal Range \\
\hline Sex & M & $\mathrm{M}$ & $\mathrm{M}$ & M & \\
\hline $\begin{array}{l}\text { Age at clinical } \\
\text { diagnosis }\end{array}$ & 35 & 37 & 46 & 25 & \\
\hline $\begin{array}{c}\text { Hemoglobin, } \mathrm{Hb} \\
(\mathrm{g} / \mathrm{L})\end{array}$ & 12.8 & 14.1 & $15^{* * *}$ & 13.1 & $\begin{array}{c}\text { M: } 13.5-17.5 \\
F: 12.1-15.1\end{array}$ \\
\hline$M C V(f l)$ & n.a. & 98.7 & $93.1^{* * *}$ & n.a. & $80-95$ \\
\hline Serum iron $(\mu g / d L)$ & 244 & 240 & $282 * * *$ & n.a. & 59-158 \\
\hline $\begin{array}{l}\text { Serum ferritin } \\
\quad(n g / m L)\end{array}$ & $\begin{array}{c}2000 \\
244^{* *}\end{array}$ & $\begin{array}{l}2000 \\
6^{* *}\end{array}$ & $66^{* * *}$ & $\begin{array}{l}2037 \\
16^{\#}\end{array}$ & $\begin{array}{l}\text { M: } 12-300 \\
\text { F: } 12-200\end{array}$ \\
\hline $\begin{array}{l}\text { Transferrin } \\
\text { (mg/dL) }\end{array}$ & n.a. & 191 & $241^{* * *}$ & n.a. & $220-400$ \\
\hline $\begin{array}{c}\text { Transferrin } \\
\text { Saturation }(\%)\end{array}$ & $\begin{array}{c}98 \\
80^{* *}\end{array}$ & $\begin{array}{l}100 \\
6^{* *}\end{array}$ & $83.6^{* * *}$ & $\begin{array}{l}94.8 \\
4.8^{\#}\end{array}$ & $20-50$ \\
\hline $\begin{array}{l}\text { Total Iron Binding } \\
\text { Capacity }(\mu g / d L)\end{array}$ & n.a. & 242.6 & n.a. & n.a. & $250-400$ \\
\hline $\begin{array}{l}\text { Hepcidin levels } \\
(\mathrm{ng} / \mathrm{mL})\end{array}$ & 0.23 & 0.01 & n.a. & n.a. & $\begin{array}{l}\text { M: } 29-254 * \\
\text { F: } 17-286 *\end{array}$ \\
\hline
\end{tabular}


Table 2. Cont.

\begin{tabular}{|c|c|c|c|c|c|}
\hline & $\begin{array}{l}\text { Family } A- \\
\text { Patient II.1 }\end{array}$ & $\begin{array}{l}\text { Family } A- \\
\text { Patient II.2 }\end{array}$ & $\begin{array}{l}\text { Family } B- \\
\text { Patient II.1 }\end{array}$ & $\begin{array}{c}\text { Family } \\
\text { C-Patient II.2 }\end{array}$ & Normal Range \\
\hline MRI liver & $\begin{array}{c}282.97 \mu \mathrm{mol} \mathrm{Fe} / \mathrm{g} \\
(\mathrm{a}) \\
15.9 \mathrm{mg} \mathrm{Fe} / \mathrm{g} \mathrm{(a)}\end{array}$ & $\begin{array}{c}265 \mu \mathrm{mol} \mathrm{Fe} / \mathrm{g}(\mathrm{b}) \\
14.9 \mathrm{mg} \mathrm{Fe} / \mathrm{g}(\mathrm{b}) \\
217.56 \mu \mathrm{mol} \mathrm{Fe} / \mathrm{g} \\
(\mathrm{c}) \\
12.22 \mathrm{mg} \mathrm{Fe} / \mathrm{g}(\mathrm{c}) \\
70.33 \mu \mathrm{mol} \mathrm{Fe} / \mathrm{g} \\
(\mathrm{d}) \\
3.95 \mathrm{mg} \mathrm{Fe} / \mathrm{g}(\mathrm{d})\end{array}$ & $\begin{array}{c}300 \mu \mathrm{mol} \mathrm{Fe} / \mathrm{g} \\
<36 \mu \mathrm{mol} \mathrm{Fe} / \mathrm{g} * * *\end{array}$ & $123.9 \mu \mathrm{mol} \mathrm{Fe} / \mathrm{g}$ & $<36 \mu \mathrm{mol} \mathrm{Fe} / \mathrm{g}$ \\
\hline Treatments & $\begin{array}{c}\text { Phlebotomy } \\
\text { Desferoxamine }\end{array}$ & $\begin{array}{c}\text { Phlebotomy } \\
\text { Desferoxamine }\end{array}$ & $\begin{array}{c}\text { Erythroapheresis } \\
\text { Phlebotomy }\end{array}$ & Phlebotomy & \\
\hline Genetics & $\begin{array}{c}\text { TFR2: } \\
\text { NM_003227.4: } \\
\text { c.2038G > T; } \\
\text { c.2038G > T } \\
\text { p.Asp680Tyr; } \\
\text { p.Asp680Tyr }\end{array}$ & $\begin{array}{c}\text { TFR2: } \\
\text { NM_003227.4: } \\
\text { c.2038G > T; } \\
\text { c.2038G > T } \\
\text { p.Asp680Tyr; } \\
\text { p.Asp680Tyr }\end{array}$ & $\begin{array}{c}\text { TFR2: } \\
\text { NM_003227.3: } \\
\text { c.2343G > A; } \\
\text { c.2343G > A } \\
\text { p.Trp781Ter; } \\
\text { p.Trp781Ter } \\
\text { HFE: } \\
\text { p.Cys282Tyr }\end{array}$ & $\begin{array}{c}\text { TFR2: } \\
\text { NM_003227.4: } \\
\text { c.2014C > T; } \\
\text { c.2014C > T } \\
\text { p.Gln672Ter; } \\
\text { p.Gln672Ter }\end{array}$ & \\
\hline
\end{tabular}

\subsection{Identification of New Mutations Associated with Non-HFE Related HH}

\subsubsection{Mutations in the HFE2 Gene}

In proband 1.II.1 (Figure 4a left), a NGS targeted diagnostic panel identified in the HFE2 gene a novel single base deletion in exon 3 (c.445delG) introducing a frameshift mutation (p.Asp149ThrfsTer97) in a homozygous state. Parents were both heterozygous for the same mutation. The parents of the proband denied consanguinity, but they both originated from the same small village in South Italy. This single base deletion generates a truncated HJV product containing the first 148 correct amino acids plus 97 incorrect residues before a premature Stop codon. This variant has an rs code (rs1553769690) with a low frequency $(\mathrm{MAF}=0.000004)$. VarSome Clinical software classifies this mutation as likely pathogenic according to ACMG rules (PVS1 and PM2). HFE testing for Cys282Tyr and His63Asp variants was negative.

Targeted NGS sequencing of the 2.II.2 proband (Figure $4 \mathrm{a}$ right) showed a novel nonsense variant in the HFE2 gene in homozygous state. This variant (c.187C > T) changes an arginine codon to a stop codon (p.Arg63Ter) that results in a truncated HJV protein. This variant is novel and has no rs code. No genetic information is available for the rest of the family. VarSome Clinical software classifies this mutation as pathogenic according to ACMG rules (PVS1, PP3 and PM2). No other variants of interest were found in any of the $\mathrm{HH}$-related genes.

Both newly discovered mutations in the HFE2 gene produce a truncated HJV protein that clearly would be non-functional, explaining the genetic cause of the non-HFE related $\mathrm{HH}$ phenotype in these probands.

\subsubsection{Mutations in the TFR2 Gene}

Genetic analysis performed in the A.II.1 and A.II.2 probands (Figure $4 \mathrm{~b}$ upper first panel) showed that both patients carry the same missense variant in homozygous state in the TFR2 gene. This previously unpublished variant (c.2038G > T) changes an aspartic acid to a tyrosine (p.Asp680Tyr). This variant has an rs code (rs1302587036) with a low frequency $(\mathrm{MAF}=0.0000319)$. Nineteen out of twenty-five bioinformatic prediction software classified this variant as unknown significance, likely pathogenic (Varsome Clinical software) according to ACMG rules (PM2, PP1, PP3 and BP1). CADD score for Asp680Tyr mutation is 
29.8. Computational analysis and modeling are discussed in the Section 3.3. Both probands are homozygous WT for the His63Asp, Ser65Cys and Cys282Tyr HFE mutations.

Regarding the B.II.1 proband, DNA analysis showed a previously reported nonsense mutation in the TFR2 gene [19]. In our patient, the variant is in homozygous state (Figure $4 \mathrm{~b}$ upper third panel). This variant (c.2343G > A) changes a tryptophan codon to a stop codon (p.Trp781Ter) that results in a truncated TFR2 protein affecting the dimerization domain of the protein. This variant has an rs code (rs768907730) with a low frequency on the general population $(\mathrm{MAF}=0.00000798)$. Nine out of ten bioinformatics prediction software classified this variant as Pathogenic (Varsome Clinical software) according to ACMG rules (PVS1, PM2, PP3 and PP5). In addition to the TFR2 mutation, our patient also carries the pathogenic p.Cys282Tyr mutant allele in the HFE gene in heterozygous state, which could aggravate the severity of the disease in this patient.

The C.II.2 proband carries a nonsense mutation (p.Gln672Ter, Figure 4b lower panel) that was previously reported in a pediatric patient in heterozygous state in combination with a second nonsense mutation in TFR2 in a Spanish patient [23]. In our patient, the mutation is in a homozygous state. This variant has an rs code (rs1051249273) with a low frequency on the general population $(\mathrm{MAF}=0.0000477)$. This nonsense mutation truncates the TFR2 protein at the beginning of the dimerization domain, clearly affecting the normal function of TFR2. Nine out of ten bioinformatic prediction software classified this variant as pathogenic (Varsome Clinical software) according to ACMG rules (PVS1, PM2 and PP3). No other mutations in $\mathrm{HH}$-related genes were found.

\subsection{Computational Studies on the TFR2 p.Asp680Tyr Mutation}

The variants in the TFR2 gene found in the B.II.1 and C.II.1 probands are clearly pathogenic since they are nonsense mutations, but the pathogenicity of the missense mutation found in family $\mathrm{A}$ is not a straightforward conclusion. To assess the genetic implications of the TFR2 p.Asp680Tyr mutation, a series of protein prediction software and structural modeling was used.

\subsubsection{Modeling the Effect of the Asp680Tyr Mutation over TFR2 Activity}

To understand the effect of the Asp680Tyr mutation over the TFR2 activity, we built a model of TFR2 complexed with transferrin (TF) based on the available crystallographic structure of the TFR1 dimer bound to TF [39]. Position 680 is located at the C-terminus end of TFR2, in its helical domain, near the TF binding and the dimeric interacting regions (Figures $5 \mathrm{~A}$ and $\mathrm{A} 3$ ). While human TFR 1 and TFR 2 share a $43 \%$ sequence identity, their amino acid sequences around the mutated region are highly conserved (Figure 5B). Moreover, a comparison between the TFR2/TF dimer model and its crystallographic TFR1/TF counterpart shows a highly similar chemical environment for the TFR2-Asp680 (TFR1-Asp648) residue (Figure 5C,D). Conversely, despite not directly contacting TF, the TFR2-Asp680 sidechain creates a network of interactions that stabilize the side-chain conformation of residue TFR2-Arg683, which participates in a critical saline bond with the TF-Asp356 residue (Figure 5D). Among the residues interacting with TFR2-Asp680, we found residue TFR2-Gln784 (Figure 5D), located at the helix $\alpha-18$, which participates in an intermolecular TFR2/TFR2 interaction with residue TFR2-Gln340, located at the loop between the $\beta-6$ and $\beta-7$ strands (Figure $5 \mathrm{~A}$ ). 

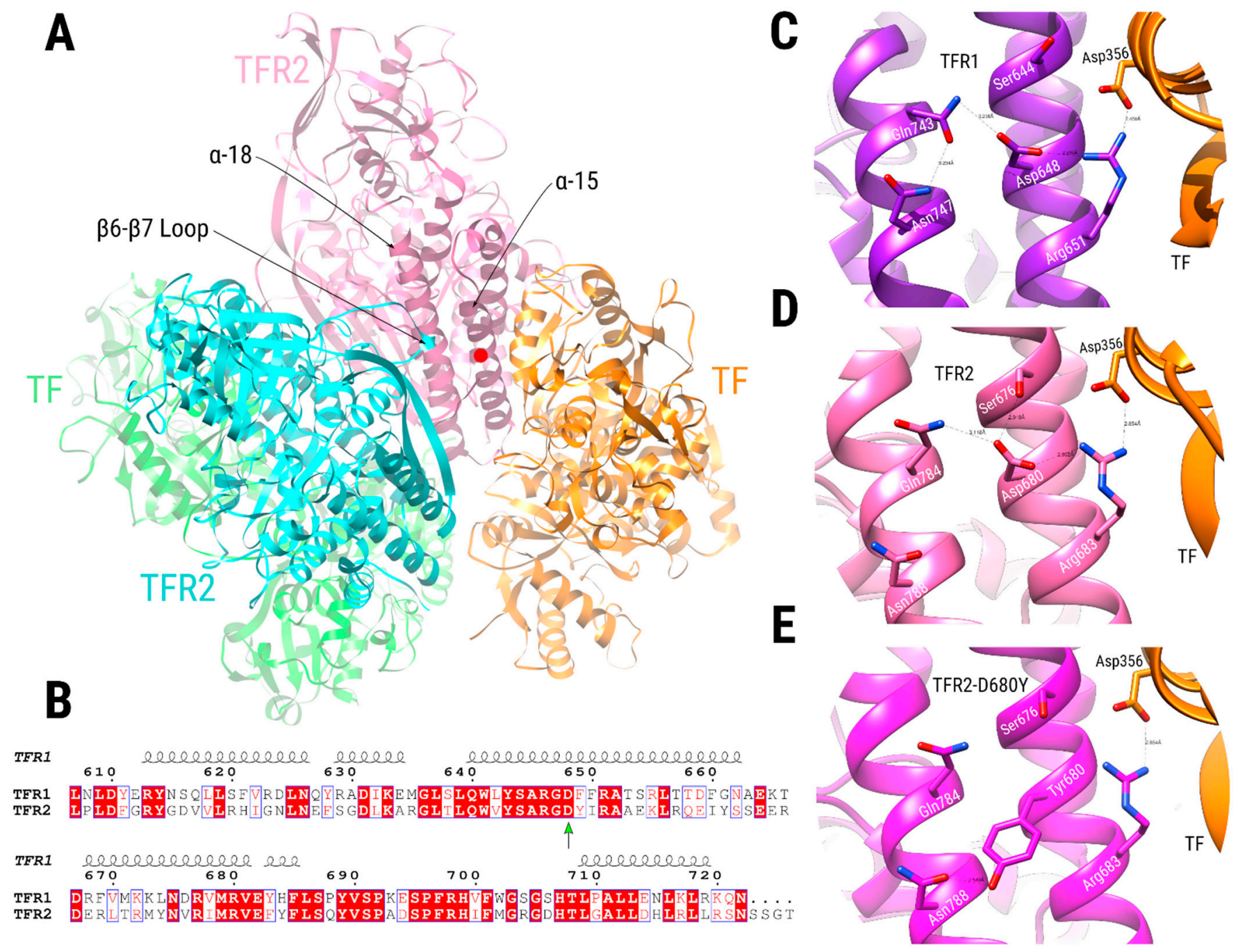

Figure 5. Comparative modeling of the TFR2 dimer complexed with TF. (A) TFR2 chains are shown in cyan and pink, while TF chains are shown in green and orange. Dimeric interactions between TFR2 chains, close to Asp680 position (red circle at the $\alpha-15$ helix, pink chain), are made between residues in the $\alpha-18$ helix of one TFR 2 chain (pink chain) and the loop located between the $\beta-6$ and $\beta-7$ strands of the other (cyan chain). (B) Sequence alignment of the TFR1 and TFR2 proteins near the TFR2 680 position (green arrow). Numbering is according to the TFR1 sequence, and the secondary structure depiction is based on the TFR1 structure (PDB ID 1CX8). The alignment coloring was produced by the ESPript 3.0 web server [40], where position with red background means absolute sequence conservation. (C-E) Structural context of positions TFR1-Asp648 (C, purple), TFR2-Asp680 (D, pink), and TFR2-Asp680Tyr (E, magenta). Residue names of TFR1/2 appear in white, while residues in TF are in black. Significant interactions are shown with dashed lines.

We modeled the TFR2-Asp680Tyr mutation over the TFR2/TF hetero-tetramer by re-optimizing the rotameric states of surrounding residues using the Rosetta all-atom force field [41]. The mutated structure shows a preference for TFR2-Tyr680 to interact with TFR2-Asn788 via a hydrogen bond (Figure 5E) while keeping hydrophobic interactions with nearby residues that stabilize its side-chain conformation. Thus, the pre-organizing role that TFR2-Asp680 plays over the TRF2-Arg683/TF-Asp356 interaction appears to be abolished when mutated for a tyrosine residue. Previous work analyzed the effect of mutations in the analogous TFR1-Asp648 position over TF binding activity [42]. They showed that a conservative mutation, Asp648Glu, diminished binding to $57 \%$ of WT activity; meanwhile, an Asp648Ala substitution reduced it to 16\%. Together, this indicates a relevant role for residue Asp680 over the TFR2 binding activity toward TF. While the TFR2-Asp680Tyr mutation could also affect the TFR2/TFR2 dimeric interaction, we expect 
it to be of a lesser extent than its effect over the TFR2/TF interaction, mainly because TFR2-Asp680 interacts via a hydrogen bond with TFR2-Gln784, an interaction that could be restored with nearby residues by the aid of bridging solvent molecules.

\subsubsection{Conservation of TFR2 Position 680 in TFR2 and TFR1 Orthologues}

Using a set of 352 orthologous sequences to TFR1 or TFR2, we built a sequence similarity network (SSN) [43] to explore the conservation of the TFR2-680 position among these proteins (Figure A2). In an SSN, nodes represent protein sequences connected by edges to other nodes if their pairwise sequence similarity is above a specified threshold. This particular SSN uses a threshold of 0.59 to define its edges and depicts orthologous sequences to TFR1 (red nodes) and TFR2 (green nodes) as two separate groups. Conservation of positions aligned with TFR2-680 is indicated by the nodes' border colors, in which $86.7 \%$ of the sequences bear an aspartate at these positions (thin black node borders). The following most relevant identity found is for a specific group of related TFR1 sequences in which all, except for one, bear serine residues $(8.8 \%)$. Other identities found in this sequence position include glycine, alanine, arginine, and proline (blue node borders); however, they are scattered around the network and are lowly represented (see the "Conservations at position 680 table" included in Figure $4 \mathrm{~b})$. Other sequences $(2.56 \%)$ do not have an alignable residue at this position (yellow node borders) since they are truncated or have deletions at this region. This result indicates high conservation of the human TFR2-Asp680 residue among many TFR1 and TFR2 orthologous sequences. Specifically, no sequence has a tyrosine or similar residue at this position, indicating a possible evolutionary penalty for its inclusion. It seems that other strategies could have evolved in other species to bind TF by TFR1 since a large cluster of TFR1-related sequences has serine as the conserved residue at this position (Figure A2).

\section{Discussion}

In this work, we described six novel cases in five families affected by non-HFE related $\mathrm{HH}$. All described patients show high levels of serum ferritin and transferrin saturation $(>86 \%)$ and present the clinical phenotype of $\mathrm{HH}$ at an earlier age (age of diagnosis 25-37 years old) as compared with HFE-related $\mathrm{HH}$. Although non-HFE related $\mathrm{HH}$ due to mutations on the HFE2 gene is classically known as juvenile hemochromatosis, cases of non-HFE related $\mathrm{HH}$ with mutations in TFR2 gene are also young patients (A.II.1 35 years old, A.II.2 37 years old, B.II.1 46 years old and C.II.2 25 years old). All patients reached normal iron, ferritin, and liver iron levels after intensive treatment, some of them combining the use of chelators and phlebotomies/erythroapheresis treatments.

We describe two novel mutations in the HFE2 gene: a nonsense mutation (p.Arg63Ter) and a single-base deletion (p.Asp149ThrfsTer97) that generate a frameshift leading to a premature stop codon. Both mutations are clearly pathogenic. At the same time, we also report a new mutation in the TFR2 gene consisting of a missense mutation (p.Asp680Tyr). Furthermore, we report a patient with a homozygous nonsense mutation (p.Gln672Ter) in the TRF2 gene in contrast with the previously reported case where the same mutation was in heterozygous state. Finally, we describe a new case of a previously reported pathogenic mutation (p.Trp781Ter).

Due to the nature of the nonsense and frameshift mutations, their pathogenicity is obvious and supported by the clear phenotypic characteristics of the patients. All of them present the hallmarks of $\mathrm{HH}$ : high serum iron and ferritin levels and low levels of hepcidin, accompanied by hepatic iron overload. In the case of the missense p.Asp680Tyr mutation, the clinical features of both patients harboring this change in the TFR2 protein are the expected for the non-HFE related HH disease (high serum iron as well as the ferritin, and transferrin saturation is high). In this line, bioinformatics analysis revealed that the Asp680Tyr mutation in the TFR2 protein alters a network of interactions that preorganize the side-chain conformation of residues in TFR2 critical for its interaction with TF. This alteration is expected to destabilize the TFR2/TF binding, negatively affecting TFR2 function 
as a TF sensor. As a possible, although less likely, secondary effect, this mutation could also affect the ability of TFR2 to dimerize, required step for its normal activity. The combination of a reduced TF binding and a possibly reduced dimerization would result in a downregulation of the signaling cascade required for HAMP expression, thus resulting in reduced hepcidin production and consequently, iron accumulation. Both biochemical and clinical features are observed in both patients (A.II.1 and A.II.2), supporting the pathogenicity of the missense mutation predicted by the computational structural modelling.

Our work highlights the importance of an earlier molecular diagnosis in a specialized center to confirm the $\mathrm{HH}$ diagnosis, its subtype, and to prevent serious complications such as liver cirrhosis, hepatocarcinoma or cardiac dysfunction in young patients by implementing a proper and earlier iron reduction treatment.

Author Contributions: Study concept and research design: M.S.; Patients' clinical data: N.J.K., E.P.A., I.H.R., A.P., S.P., M.À.R.M., G.G.R. and E.C.G.; Sequencing and mutation validation: X.F.-C., V.V., M.M., M.S. and C.T.; Computational modeling: M.F.P., P.M.M.T. and J.V.-F.; Writing of the manuscript: G.H., V.V. and M.S.; Funding recruitment: M.S., S.P.-M. and C.T. All authors have read and agreed to the published version of the manuscript.

Funding: This study was supported by the grant RTI-2018-101735-B-I100 (MCI/AEI/FEDER, EU) from the Spanish Ministry of Science and Innovation (MICINN) to M.S. G.H. is supported by funds provided by the APU and ADISCON Patient associations. X.F.-C. is partially supported by funds provided by the grant RTI-2018-101735-B-I100 (MCI/AEI/FEDER, EU). V.V. is supported by funds provided by APU and ADISCON patient associations and is currently supported by funds provided by UIC postdoctoral scholarship and by funds provided by RETOS COLABORACION grant RTC2019007074-1 (MCI/AEI/FEDER, EU) from the Spanish Ministry of Science and Innovation (MICINN). The work by M.F.P., P.M.M.T. and J.V.-F. has been developed within the BIO2017-83650-P project, funded by the Spanish Subprograma Estatal de Generación del Conocimiento. M.M. is supported by a Marie Curie Fellowship grant from the European Commission.

Institutional Review Board Statement: The study protocol conforms to the ethical guidelines of the 2002 Helsinki declaration. Protocol was approved by Hospital General de Cataluña on date 24 October 2018.

Informed Consent Statement: Written informed consent for molecular genetic analyses was obtained from the probands and relatives of the families according to the guidelines of our institution.

Data Availability Statement: Data is available upon request.

Acknowledgments: We are grateful to all families who kindly contributed to this study. We would like to thank Nicola Zucchini for performing and analyzing the liver biopsy of the patient 1.II.1.

Conflicts of Interest: C.T. is CEO of BloodGenetics, S.L. and M.S. are co-founders of BloodGenetics.

\section{Appendix A}

Table A1. List of patients diagnosed with non-HFE related HH with mutations in the HFE2 gene. The domain localization of the mutations is described according to the Figure 2 representations.

\begin{tabular}{cccccccc}
\hline \multirow{2}{*}{$\begin{array}{c}\text { Patient } \\
\text { Number }\end{array}$} & $\begin{array}{c}\mathbf{N}^{\circ} \\
\text { Families }\end{array}$ & Ancestry & \multicolumn{2}{c}{ Molecular Defects. HJV Protein: NP_998818.1. HFE2 Gene: NM_213653.4 } \\
\cline { 3 - 6 } & 1 & Greece & Ile281Thr & Mature Protein & Ile281Thr & Mature Protein & [22] \\
\hline 1 & 2 & Japan & Ile281Thr & Mature Protein & Ile281Thr & Mature Protein & [22] \\
\hline 2 & 2 & Japan & Ile281Thr & Mature Protein & Ile281Thr & Mature Protein & [22] \\
\hline 3 & 3 & China & Ile281Thr & Mature Protein & Cys321Ter & Mature Protein & [22] \\
\hline 4 & 4 & China & Ile281Thr & Mature Protein & Cys321Ter & Mature Protein & [22] \\
\hline 5 & 4 & China & Ile281Thr & Mature Protein & Cys321Ter & Mature Protein & [22] \\
\hline 6 & & & & & & &
\end{tabular}


Table A1. Cont.

\begin{tabular}{|c|c|c|c|c|c|c|c|}
\hline \multirow{2}{*}{$\begin{array}{l}\text { Patient } \\
\text { Number }\end{array}$} & \multirow{2}{*}{$\begin{array}{c}\mathbf{N}^{\circ} \\
\text { Families }\end{array}$} & \multirow[b]{2}{*}{ Ancestry } & \multicolumn{4}{|c|}{ Molecular Defects. HJV Protein: NP_998818.1. HFE2 Gene: NM_213653.4 } & \multirow[b]{2}{*}{ Reference } \\
\hline & & & Mutation 1 & $\begin{array}{c}\text { Domain } \\
\text { Mutation } 1\end{array}$ & Mutation 2 & $\begin{array}{c}\text { Domain } \\
\text { Mutation } 2\end{array}$ & \\
\hline 7 & 5 & China & Ile281Thr & Mature Protein & Cys208Ter/Arg6Se & $\begin{array}{c}\text { Mature } \\
\text { Protein/Signal } \\
\text { peptide }\end{array}$ & [22] \\
\hline 8 & 6 & Canada & Ile222Asn & Mature Protein & Gly320Val & Mature Protein & [22] \\
\hline 9 & 7 & Greece & Gly320Val & Mature Protein & Gly320Val & Mature Protein & [22] \\
\hline 10 & 8 & Greece & Gly320Val & Mature Protein & Gly320Val & Mature Protein & [22] \\
\hline 11 & 9 & Greece & Gly320Val & Mature Protein & Gly320Val & Mature Protein & [22] \\
\hline 12 & 10 & Greece & Gly320Val & Mature Protein & Gly320Val & Mature Protein & [22] \\
\hline 13 & 11 & Greece & Cys361fsTer366 & Mature Protein & Cys361fsTer366 & Mature Protein & [22] \\
\hline 14 & 12 & Greece & Gly99Val & Mature Protein & Gly99Val & Mature Protein & [22] \\
\hline 15 & 13 & Greece & Gly320Val & Mature Protein & Gly320Val & Mature Protein & [22] \\
\hline 16 & 14 & Greece & Gly320Val & Mature Protein & Arg326Ter & Mature Protein & [22] \\
\hline 17 & 15 & Greece & Gly320Val & Mature Protein & Gly320Val & Mature Protein & [22] \\
\hline 18 & 16 & France & Gly320Val & Mature Protein & Gly320Val & Mature Protein & [22] \\
\hline 19 & 17 & China & Cys321Ter & Mature Protein & His104Arg & Mature Protein & [22] \\
\hline 20 & 18 & China & Cys321Ter & Mature Protein & Val274Met & Mature Protein & [22] \\
\hline 21 & 19 & China & Gln312Ter & Mature Protein & Gln312Ter & Mature Protein & [22] \\
\hline 22 & 20 & China & Phe103Leu & Mature Protein & Phe103Leu & Mature Protein & [22] \\
\hline 23 & 21 & France & Gly320Val & Mature Protein & Gly320Val & Mature Protein & [22] \\
\hline 24 & 22 & France & Gly320Val & Mature Protein & Gly320Val & Mature Protein & [22] \\
\hline 25 & 23 & $\begin{array}{l}\text { France } \\
\text { (North } \\
\text { African) }\end{array}$ & Arg385Ter & Mature Protein & Arg385Ter & Mature Protein & [22] \\
\hline 26 & 24 & France & His180Arg & Mature Protein & Leu101Pro & Mature Protein & [22] \\
\hline 27 & 25 & France & Ala384Val & Mature Protein & Arg288Trp & Mature Protein & [22] \\
\hline 28 & 26 & France & Gly320Val & Mature Protein & Gly320Val & Mature Protein & [22] \\
\hline 29 & 27 & $\begin{array}{c}\text { African } \\
\text { American }\end{array}$ & Arg54Ter & Mature Protein & Arg54Ter & Mature Protein & [22] \\
\hline 30 & 28 & Romania & Gly66Ter & Mature Protein & Gly66Ter & Mature Protein & [22] \\
\hline 31 & 29 & Japan & Tyr150Cys & Mature Protein & Val274Met & Mature Protein & [22] \\
\hline 32 & 30 & United States & Cys80Arg & Mature Protein & Leu101Pro & Mature Protein & [22] \\
\hline 33 & 31 & United States & Cys80Arg & Mature Protein & Leu101Pro & Mature Protein & [22] \\
\hline 34 & 31 & United States & Leu101Pro & Mature Protein & Leu101Pro & Mature Protein & [22] \\
\hline 35 & 31 & United States & Leu101Pro & Mature Protein & Leu101Pro & Mature Protein & [22] \\
\hline 36 & 31 & United States & Leu101Pro & Mature Protein & Leu101Pro & Mature Protein & [22] \\
\hline 37 & 31 & United States & Leu101Pro & Mature Protein & Leu101Pro & Mature Protein & [22] \\
\hline
\end{tabular}


Table A1. Cont.

\begin{tabular}{|c|c|c|c|c|c|c|c|}
\hline \multirow{2}{*}{$\begin{array}{l}\text { Patient } \\
\text { Number }\end{array}$} & \multirow{2}{*}{$\begin{array}{c}\mathbf{N}^{\circ} \\
\text { Families }\end{array}$} & \multirow[b]{2}{*}{ Ancestry } & \multicolumn{4}{|c|}{ Molecular Defects. HJV Protein: NP_998818.1. HFE2 Gene: NM_213653.4 } & \multirow[b]{2}{*}{ Reference } \\
\hline & & & Mutation 1 & $\begin{array}{c}\text { Domain } \\
\text { Mutation } 1\end{array}$ & Mutation 2 & $\begin{array}{c}\text { Domain } \\
\text { Mutation } 2\end{array}$ & \\
\hline 38 & 32 & United States & Ile222Asn & Mature Protein & Gly320Val & Mature Protein & [22] \\
\hline 39 & 33 & Bangladesh & Cys80Tyr & Mature Protein & Gly320Val & Mature Protein & [22] \\
\hline 40 & 34 & Pakistan & Gly99Arg & Mature Protein & Gly99Arg & Mature Protein & [22] \\
\hline 41 & 35 & Pakistan & Gly99Arg & Mature Protein & Gly99Arg & Mature Protein & [22] \\
\hline 42 & 36 & Pakistan & Pro192Leu & Mature Protein & Pro192Leu & Mature Protein & [22] \\
\hline 43 & 37 & Pakistan & Leu194Pro & Mature Protein & Leu194Pro & Mature Protein & [22] \\
\hline 44 & 38 & Sri Lanka & Ala343ProfsTer23 & Mature Protein & Ala343ProfsTer23 & Mature Protein & [22] \\
\hline 45 & 39 & Australia & Gly320Val & Mature Protein & Gly320Val & Mature Protein & [22] \\
\hline 46 & 40 & Australia & Cys80Arg & Mature Protein & Arg326Ter & Mature Protein & [22] \\
\hline 47 & 41 & Australia & Gly320Val & Mature Protein & Gly320Val & Mature Protein & [22] \\
\hline 48 & 42 & Italy & Arg385Ter & Mature Protein & Arg385Ter & Mature Protein & [22] \\
\hline 49 & 43 & Italy & Phe170Ser & Mature Protein & Phe170Ser & Mature Protein & [22] \\
\hline 50 & 44 & Italy & Trp191Cys & Mature Protein & Trp191Cys & Mature Protein & [22] \\
\hline 51 & 45 & Italy & Arg385Ter & Mature Protein & Arg385Ter & Mature Protein & [22] \\
\hline 52 & 46 & Italy & Asp149fsTer245 & Mature Protein & Asp149fsTer245 & Mature Protein & [22] \\
\hline 53 & 47 & Italy & Ser205Arg & Mature Protein & Gly250Val & Mature Protein & [22] \\
\hline 54 & 48 & Italy & Phe170Ser & Mature Protein & Phe170Ser & Mature Protein & [22] \\
\hline 55 & 49 & Italy & Val74fsTer113 & Mature Protein & Asn269fsTer311 & Mature Protein & [22] \\
\hline 56 & 49 & Italy & Asp149fsTer245 & Mature Protein & Asp149fsTer245 & Mature Protein & [22] \\
\hline 57 & 50 & Italy & Arg131fsTer245 & Mature Protein & Arg131fsTer245 & Mature Protein & [22] \\
\hline 58 & 51 & Canada/Italy & Gly320Val & Mature Protein & Gly320Val & Mature Protein & [22] \\
\hline 59 & 52 & Italy & Ser85Pro & Mature Protein & Ser85Pro & Mature Protein & [22] \\
\hline 60 & 53 & France & Arg288Trp & Mature Protein & Arg288Trp & Mature Protein & [22] \\
\hline 61 & 54 & Italy & Asp172E & Mature Protein & Gly319fsTer341 & Mature Protein & [22] \\
\hline 62 & 55 & Australia/English & h Ala168Asp & Mature Protein & Ala168Asp & Mature Protein & [22] \\
\hline 63 & 56 & Albania & Leu101Pro & Mature Protein & Gly99Arg & Mature Protein & [22] \\
\hline 64 & 57 & Italy & Asp149fsTer245 & Mature Protein & Asp149fsTer245 & Mature Protein & [22] \\
\hline 65 & 58 & Canada/Italy & Gly320Val & Mature Protein & Gly320Val & Mature Protein & [22] \\
\hline 66 & 59 & Iran & Cys89Arg & Mature Protein & Cys89Arg & Mature Protein & [22] \\
\hline 67 & 59 & Iran & Cys89Arg & Mature Protein & Cys89Arg & Mature Protein & [22] \\
\hline 68 & 60 & English/Ireland & Gly320Val & Mature Protein & Gln116Ter & Mature Protein & [22] \\
\hline 69 & 61 & Croatia & Gly320Val & Mature Protein & Gly320Val & Mature Protein & [22] \\
\hline 70 & 62 & Germany & Gly320Val & Mature Protein & Gly320Val & Mature Protein & [22] \\
\hline 71 & 63 & Germany & Gly320Val & Mature Protein & Gly320Val & Mature Protein & [22] \\
\hline 72 & 64 & Slovakia & Gly320Val & Mature Protein & Ser328fsTer337 & Mature Protein & [22] \\
\hline 73 & 64 & Slovakia & Gly320Val & Mature Protein & Ser328fsTer337 & Mature Protein & [22] \\
\hline 74 & 65 & Germany & Gly320Val & Mature Protein & Gly320Val & Mature Protein & [22] \\
\hline 75 & 66 & Germany & Cys119Phe & Mature Protein & Cys119Phe & Mature Protein & [22] \\
\hline 76 & 67 & Netherland & Leu165Ter & Mature Protein & Leu165Ter & Mature Protein & [22] \\
\hline
\end{tabular}


Table A1. Cont.

\begin{tabular}{|c|c|c|c|c|c|c|c|}
\hline \multirow{2}{*}{$\begin{array}{l}\text { Patient } \\
\text { Number }\end{array}$} & \multirow{2}{*}{$\begin{array}{c}\mathbf{N}^{\circ} \\
\text { Families }\end{array}$} & \multirow{2}{*}{ Ancestry } & \multicolumn{4}{|c|}{ Molecular Defects. HJV Protein: NP_998818.1. HFE2 Gene: NM_213653.4 } & \multirow[b]{2}{*}{ Reference } \\
\hline & & & Mutation 1 & $\begin{array}{c}\text { Domain } \\
\text { Mutation } 1\end{array}$ & Mutation 2 & $\begin{array}{c}\text { Domain } \\
\text { Mutation } 2\end{array}$ & \\
\hline 77 & 68 & France & Arg176Cys & Mature Protein & Arg176Cys & Mature Protein & [22] \\
\hline 78 & 69 & France & Gly320Val & Mature Protein & Arg176Cys & Mature Protein & [22] \\
\hline 79 & 70 & Japan & Asp249His & Mature Protein & Asp249His & Mature Protein & [22] \\
\hline 80 & 71 & Japan & Gln312Ter & Mature Protein & Gln312Ter & Mature Protein & [22] \\
\hline 81 & 72 & Japan & Gln312Ter & Mature Protein & Gln312Ter & Mature Protein & [22] \\
\hline 82 & 73 & Caucasian & Gly320Val & Mature Protein & Cys321Trp & Mature Protein & [22] \\
\hline 83 & 74 & India & Asp355Tyr & Mature Protein & Asp355Tyr & Mature Protein & [22] \\
\hline 84 & 74 & India & Asp355Tyr & Mature Protein & Asp355Tyr & Mature Protein & [22] \\
\hline 85 & 75 & Romania & Gly320Val & Mature Protein & Gly320Val & Mature Protein & [22] \\
\hline 86 & 76 & Caucasian & Gly320Val & Mature Protein & Gly320Val & Mature Protein & [22] \\
\hline 87 & 77 & Italy & Cys317Ser & Mature Protein & Cys317Ser & Mature Protein & [22] \\
\hline 88 & 78 & India & Gly336Ter & Mature Protein & Gly336Ter & Mature Protein & [22] \\
\hline 89 & 79 & India & Gly336Ter & Mature Protein & Gly336Ter & Mature Protein & [22] \\
\hline 90 & 80 & India & Gly336Ter & Mature Protein & Gly336Ter & Mature Protein & [22] \\
\hline 91 & 81 & India & Gly336Ter & Mature Protein & Gly336Ter & Mature Protein & [22] \\
\hline 92 & 82 & India & $\begin{array}{c}5^{\prime} \mathrm{UTR}-358(\mathrm{G}> \\
\mathrm{A})\end{array}$ & - & $\begin{array}{c}5^{\prime} \mathrm{UTR}-358(\mathrm{G} \\
>\mathrm{A})\end{array}$ & - & [22] \\
\hline 93 & 83 & India & $\begin{array}{c}5^{\prime} \mathrm{UTR}-358(\mathrm{G}> \\
\mathrm{A})\end{array}$ & - & $\begin{array}{c}5^{\prime} \mathrm{UTR}-358(\mathrm{G} \\
>\mathrm{A})\end{array}$ & - & [22] \\
\hline 94 & 84 & China & Cys321Ter & Mature Protein & Gln6His & Signal Peptide & [22] \\
\hline 95 & 85 & English/Ireland & Leu28SerfsTer24 & Signal Peptide & Leu28SerfsTer24 & Signal Peptide & [22] \\
\hline 96 & 86 & Brazil & Gln233fsTer245 & Mature Protein & Gln233fsTer245 & Mature Protein & [22] \\
\hline 97 & 87 & Saudi Arabia & His166Arg & Mature Protein & His166Arg & Mature Protein & [23] \\
\hline 98 & 87 & Saudi Arabia & His166Arg & Mature Protein & His166Arg & Mature Protein & [23] \\
\hline 99 & 88 & Spain & Asp149ThrfsTer97 & Mature Protein & Asp149ThrfsTer97 & Mature Protein & $\begin{array}{l}\text { This } \\
\text { work }\end{array}$ \\
\hline 100 & 89 & Spain & Arg63Ter & Mature Protein & Arg63Ter & Mature Protein & $\begin{array}{l}\text { This } \\
\text { work }\end{array}$ \\
\hline
\end{tabular}

Table A2. List of patients diagnosed with non-HFE related HH with mutations in the TFR2 gene. The domain localization of the mutations is described according to Figure 3 representations.

\begin{tabular}{|c|c|c|c|c|c|c|c|}
\hline \multirow[b]{2}{*}{ Ancestry } & \multirow{2}{*}{$\begin{array}{c}\mathbf{N}^{\circ} \\
\text { Families }\end{array}$} & \multirow{2}{*}{$\begin{array}{c}\mathbf{N}^{\circ} \text { Affected } \\
\text { Patients }\end{array}$} & \multicolumn{4}{|c|}{ Molecular Defects. TFR2 Protein: NP_003218.2. TFR2 Gene: NM_003227.3 } & \multirow[b]{2}{*}{ Reference } \\
\hline & & & Mutation 1 & $\begin{array}{c}\text { Domain } \\
\text { Mutation } 1\end{array}$ & Mutation 2 & $\begin{array}{c}\text { Domain } \\
\text { Mutation } 2\end{array}$ & \\
\hline Iranian & 1 & 1 & $\begin{array}{c}\text { AVAQ 621_624del } \\
\text { (reported as AVAQ } \\
\text { 594_597del) }\end{array}$ & Extracellular & $\begin{array}{c}\text { AVAQ 621_624del } \\
\text { (reported as AVAQ } \\
594 \_597 \mathrm{del} \text { ) }\end{array}$ & Extracellular & [24] \\
\hline Spanish & 1 & 1 & p.Gly373Asp & Extracellular & Not found & - & [24] \\
\hline Spanish & 1 & 1 & p.Arg420His & Extracellular & Not found & - & [24] \\
\hline Italian & 1 & 1 & c. $614+4 \mathrm{~A}>\mathrm{G}$ & Intronic & c. $614+4 \mathrm{~A}>\mathrm{G}$ & Intronic & [24] \\
\hline
\end{tabular}


Table A2. Cont.

\begin{tabular}{|c|c|c|c|c|c|c|c|}
\hline \multirow{2}{*}{ Ancestry } & \multirow{2}{*}{$\begin{array}{c}\mathrm{N}^{\circ} \\
\text { Families }\end{array}$} & \multirow{2}{*}{$\begin{array}{c}\mathrm{N}^{\circ} \\
\text { Affected } \\
\text { Patients }\end{array}$} & \multicolumn{4}{|c|}{ Molecular Defects. TFR2 Protein: NP_003218.2. TFR2 Gene: NM_003227.3 } & \multirow[b]{2}{*}{ Reference } \\
\hline & & & Mutation 1 & $\begin{array}{c}\text { Domain } \\
\text { Mutation } 1\end{array}$ & Mutation 2 & $\begin{array}{c}\text { Domain } \\
\text { Mutation } 2\end{array}$ & \\
\hline & 1 & 1 & p.Phe280Leu & PA & Not found & - & [24] \\
\hline Italian & 1 & 1 & p.Arg396Ter & Extracellular & c. $1538-2 \mathrm{~A}>\mathrm{G}$ & Intronic & [24] \\
\hline Italian & 1 & 1 & p.Asn411del & Extracellular & p.Ala444Thr & Peptidase M28 & [24] \\
\hline Italian & 1 & 2 & $\begin{array}{l}\text { c. } 2137-1 \mathrm{G}>\mathrm{A} \\
\text { (reported as IVS17 } \\
\quad+5636 \mathrm{G}>\mathrm{A} \text { ) }\end{array}$ & Intronic & $\begin{array}{c}\text { c. } 2137-1 \mathrm{G}>\mathrm{A} \\
\text { (reported as IVS17 } \\
\quad+5636 \mathrm{G}>\mathrm{A})\end{array}$ & Intronic & [24] \\
\hline $\begin{array}{l}\text { Native Amer- } \\
\text { ican/white }\end{array}$ & 1 & 1 & p.Asp189N & Extracellular & $\begin{array}{l}\text { Not found in TFR2, } \\
\text { HAMP promoter } \\
\text { mutation }-443 \mathrm{C}> \\
\text { T in heterozygosity }\end{array}$ & - & [24] \\
\hline Taiwanese & 1 & 1 & $\begin{array}{l}\text { p.Arg468His } \\
\text { (reported as } \\
\text { p.Arg481His) }\end{array}$ & Peptidase M28 & Not found & - & [24] \\
\hline Italian & 1 & 2 & p.Met172Lys & Extracellular & p.Met172Lys & Extracellular & [24] \\
\hline $\begin{array}{l}\text { Scoth-Irish } \\
\text { American }\end{array}$ & 1 & 1 & p.Arg396Ter & Arg396Ter & p.Arg455Gln & Peptidase M28 & [24] \\
\hline Italian & 1 & 3 & p.Gln317Ter & Extracellular & p.Gln317Ter & Extracellular & [24] \\
\hline Japanese & 1 & 1 & $\begin{array}{l}\text { p.Ser556AlafsTer6 } \\
\text { (reported as } \\
\text { p.Val561Ter }\end{array}$ & Peptidase M28 & $\begin{array}{l}\text { p.Ser556AlafsTer6 } \\
\text { (reported as } \\
\text { p.Val561Ter }\end{array}$ & Peptidase M28 & [24] \\
\hline Japanese & 1 & 1 & p.Leu490Arg & Peptidase M28 & p.Leu490Arg & Peptidase M28 & [24] \\
\hline $\begin{array}{l}\text { North } \\
\text { French }\end{array}$ & 1 & 2 & p.Arg105Ter & Near TM & p.Arg105Ter & Near TM & [24] \\
\hline Italian & 2 & 2 & p.Tyr250Ter & PA & p.Tyr250Ter & PA & {$[24]$} \\
\hline Japanese & 1 & 3 & $\begin{array}{c}\text { AVAQ 621_624del } \\
\text { (reported as AVAQ } \\
\text { 594_597del) }\end{array}$ & Extracellular & $\begin{array}{c}\text { AVAQ 621_624del } \\
\text { (reported as AVAQ } \\
\text { 594_597del) }\end{array}$ & Extracellular & [24] \\
\hline Italian & 3 & 3 & p.Val22Ile & Near Endo & $\begin{array}{l}\text { Not found in TFR2 } \\
\text { (1 patient also } \\
\text { homozygous for } \\
\text { HFE Cys282Tyr) }\end{array}$ & - & [24] \\
\hline Italian & 1 & 3 & $\begin{array}{c}\text { AVAQ 621_624del } \\
\text { (reported as AVAQ } \\
594 \_597 \mathrm{del} \text { ) }\end{array}$ & Extracellular & $\begin{array}{c}\text { AVAQ 621_624del } \\
\text { (reported as AVAQ } \\
594 \text { 597del) }\end{array}$ & Extracellular & [24] \\
\hline Portuguese & 1 & 3 & p.Gln690Pro & TFR Dimeric & p.Gln690Pro & TFR Dimeric & [24] \\
\hline Asiatic & 1 & 1 & p.Arg455Gln & Peptidase M28 & $\begin{array}{c}\text { not found in TFR2 } \\
\text { (patient also } \\
\text { homozygous for } \\
\text { HFE Cys282Tyr) }\end{array}$ & - & [24] \\
\hline Italian & 1 & 6 & $\begin{array}{l}\text { p.Arg30ProfsTer31 } \\
\text { (reported as } \\
\text { p.Glu60Ter) }\end{array}$ & Cytosolic & $\begin{array}{l}\text { p.Arg30ProfsTer31 } \\
\text { (reported as } \\
\text { p.Glu60Ter) }\end{array}$ & Cytosolic & [24] \\
\hline Italian & 1 & 1 & p.Met172Lys & Extracellular & p.Met172Lys & Extracellular & [24] \\
\hline Italian & 2 & 6 & p.Tyr250Ter & PA & p.Tyr250Ter & PA & [24] \\
\hline Spanish & 1 & 1 & p.Phe280Leu & PA & $\begin{array}{l}\text { not found in TFR2 } \\
\text { (patient also } \\
\text { heterozygous for } \\
\text { HFE His63Asp) }\end{array}$ & - & [24] \\
\hline African & 1 & 1 & p.Gly430Arg & Peptidase M28 & p.Tyr504Cys & Peptidase M28 & [24] \\
\hline Italian & 1 & 1 & p.Thr740Met & TFR Dimeric & p.Thr740Met & TFR Dimeric & [24] \\
\hline Italian & 1 & 1 & p.Leu615ProfsTer177 & $\begin{array}{c}\text { Near Peptidase } \\
\text { M28 }\end{array}$ & Not found & - & [24] \\
\hline Italian & 1 & 1 & p.Ser531GlnfsTer6 & Peptidase M28 & Not found & - & [24] \\
\hline
\end{tabular}


Table A2. Cont.

\begin{tabular}{|c|c|c|c|c|c|c|c|}
\hline \multirow{2}{*}{ Ancestry } & \multirow{2}{*}{$\begin{array}{c}\mathbf{N}^{\circ} \\
\text { Families }\end{array}$} & \multirow{2}{*}{$\begin{array}{c}\mathrm{N}^{\circ} \\
\text { Affected } \\
\text { Patients }\end{array}$} & \multicolumn{4}{|c|}{ Molecular Defects. TFR2 Protein: NP_003218.2. TFR2 Gene: NM_003227.3 } & \multirow[b]{2}{*}{ Reference } \\
\hline & & & Mutation 1 & $\begin{array}{c}\text { Domain } \\
\text { Mutation } 1\end{array}$ & Mutation 2 & $\begin{array}{c}\text { Domain } \\
\text { Mutation } 2\end{array}$ & \\
\hline French & 1 & 1 & p.Arg678Pro & TFR Dimeric & p.Arg678Pro & TFR Dimeric & [24] \\
\hline French & 1 & 1 & p.Asn412Ile & Extracellular & p.Asn412Ile & Extracellular & [24] \\
\hline North Africa & 1 & 1 & p.Gly430Arg & Peptidase M28 & p.Gly430Arg & Extracellular & [24] \\
\hline French & 1 & 1 & p.Leu85_Ala96delinsPro & $\mathrm{TM}$ & p.Gly735Ser & TFR Dimeric & [24] \\
\hline French & 1 & 1 & p.Ala444Thr & Peptidase M28 & p.Gly792Arg & TFR Dimeric & [24] \\
\hline French & 1 & 1 & p.Arg730Cys & TFR Dimeric & p.Trp781Ter & TFR Dimeric & [24] \\
\hline French & 1 & 1 & p.Met705HisfsTer87 & TFR Dimeric & p.Gly792Arg & TFR Dimeric & [24] \\
\hline Spanish & 1 & 2 & p.Gly792Arg & TFR Dimeric & p.Gly792Arg & TFR Dimeric & [24] \\
\hline Spanish & 1 & 1 & p.Gly792Arg & TFR Dimeric & c. $1606-8 \mathrm{~A}>\mathrm{G}$ & Intronic & [24] \\
\hline Spanish & 1 & 1 & p.Gln306Ter & $\mathrm{PA}$ & p.Gln672Ter & TFR Dimeric & [24] \\
\hline Mexican & 1 & 1 & p.Ser470Ile & Peptidase M28 & p.Ser470Ile & Peptidase M28 & [25] \\
\hline Spanish & 1 & 1 & p.Trp781Ter & TFR Dimeric & p.Trp781Ter & TFR Dimeric & $\begin{array}{l}\text { This } \\
\text { work }\end{array}$ \\
\hline Asiatic & 1 & 2 & p.Asp680Tyr & TFR Dimeric & p.Asp680Tyr & TFR Dimeric & $\begin{array}{l}\text { This } \\
\text { work }\end{array}$ \\
\hline Spanish & 1 & 1 & p.Gln672Ter & TFR Dimeric & p.Gln672Ter & TFR Dimeric & $\begin{array}{l}\text { This } \\
\text { work }\end{array}$ \\
\hline
\end{tabular}

a)

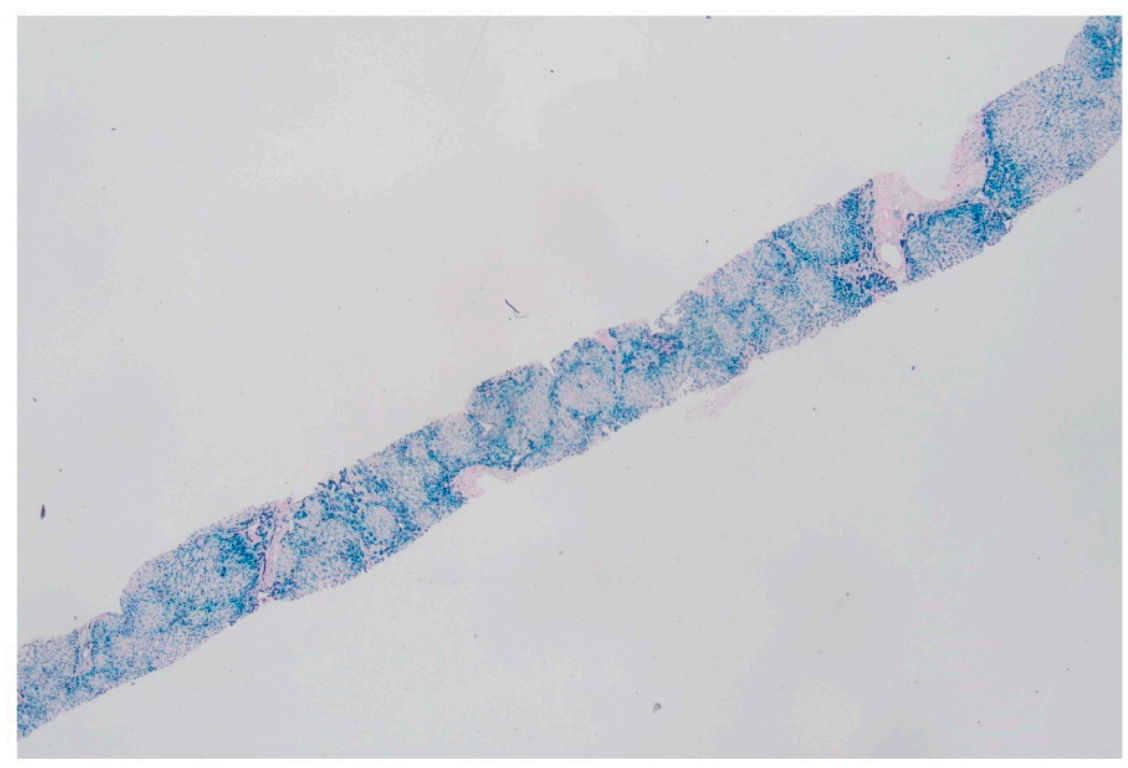

Figure A1. Cont. 
b)

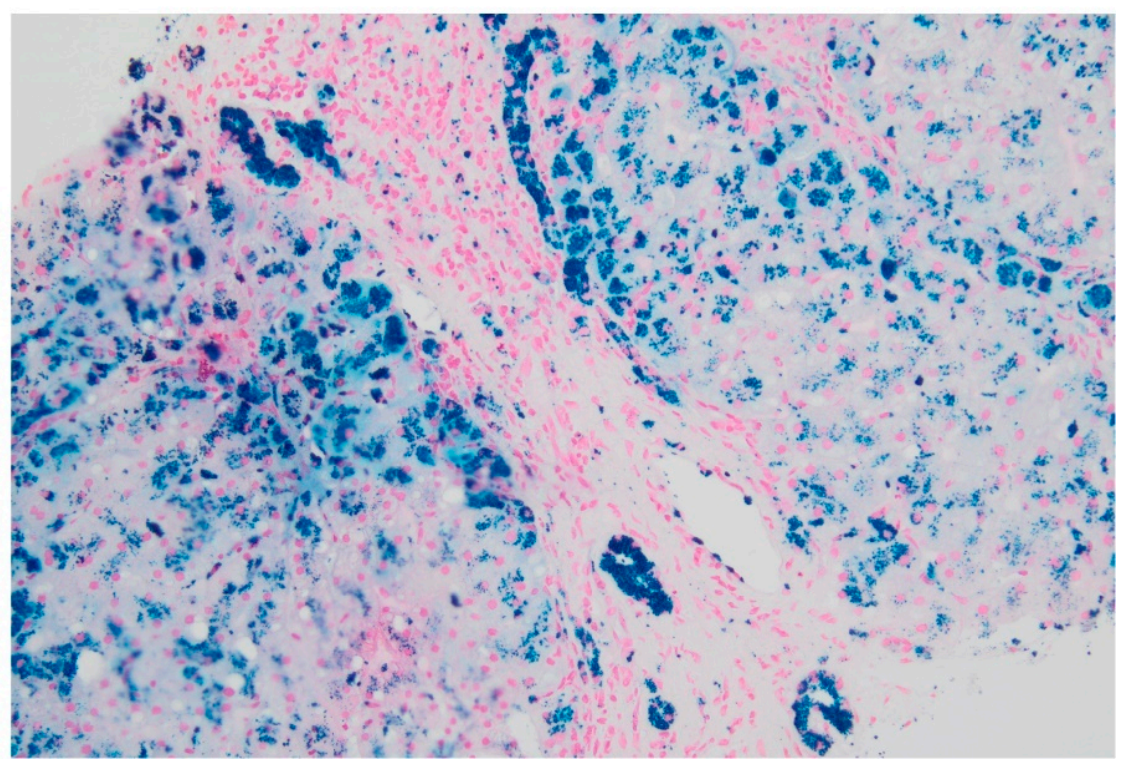

Figure A1. Liver biopsy of a patient with HJV-related hemochromatosis. (a). The specimen contains several pseudo-lobules and shows massive iron overload in Rappaport zone 1 and decreasing hemosiderin gradient from Rappaport zone 1 to 3 (Perls' Prussian blue stain, 2X magnification). (b) A magnification $(20 \times)$ of the previous image focusing a portal tract and part of the hepatic lobules showing massive hemosiderin granules in hepatocytes, biliocytes, macrophages and portal vein endothelium. Deugnier's score: Total Iron Score 51 (Hepatic Iron Score 12,9,9; Sinusoidal Iron Score 3,3,3; Portal Iron score 4,4,4). 


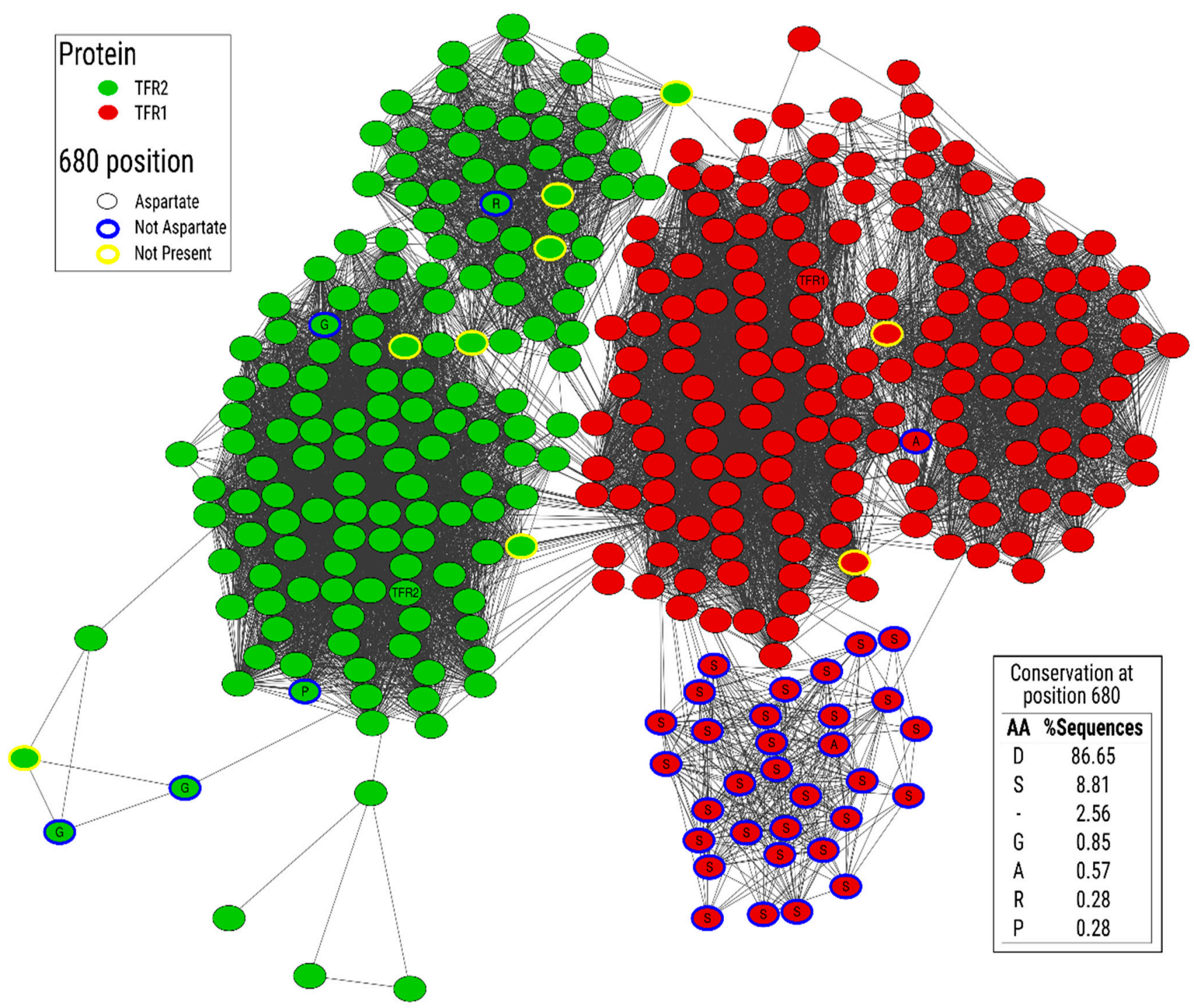

Figure A2. Sequence similarity network for TFR1 and TFR2 orthologous proteins. Three hundred fifty-two sequences were used, where each node represents an orthologous sequence to the human TFR1 (red nodes) or TFR2 (green nodes) proteins. Edges are drawn between two nodes if their sequence similarity is higher than 0.59 . Node border colors indicate amino acid identities of positions aligned with the human TFR2 position 680. Sequences with aspartate at this position have thin black borders. Sequences with an identity different from aspartate appear with thick blue borders. Finally, sequences with no residue aligned at this position appear with yellow node borders. Nodes representing the human TFR1 and TFR2 sequences have labels indicating their protein name. The right bottom table indicates the percentage of sequences bearing a particular amino acid identity (or lack of it: '-') at the position aligned with the human TFR2 position 680. 


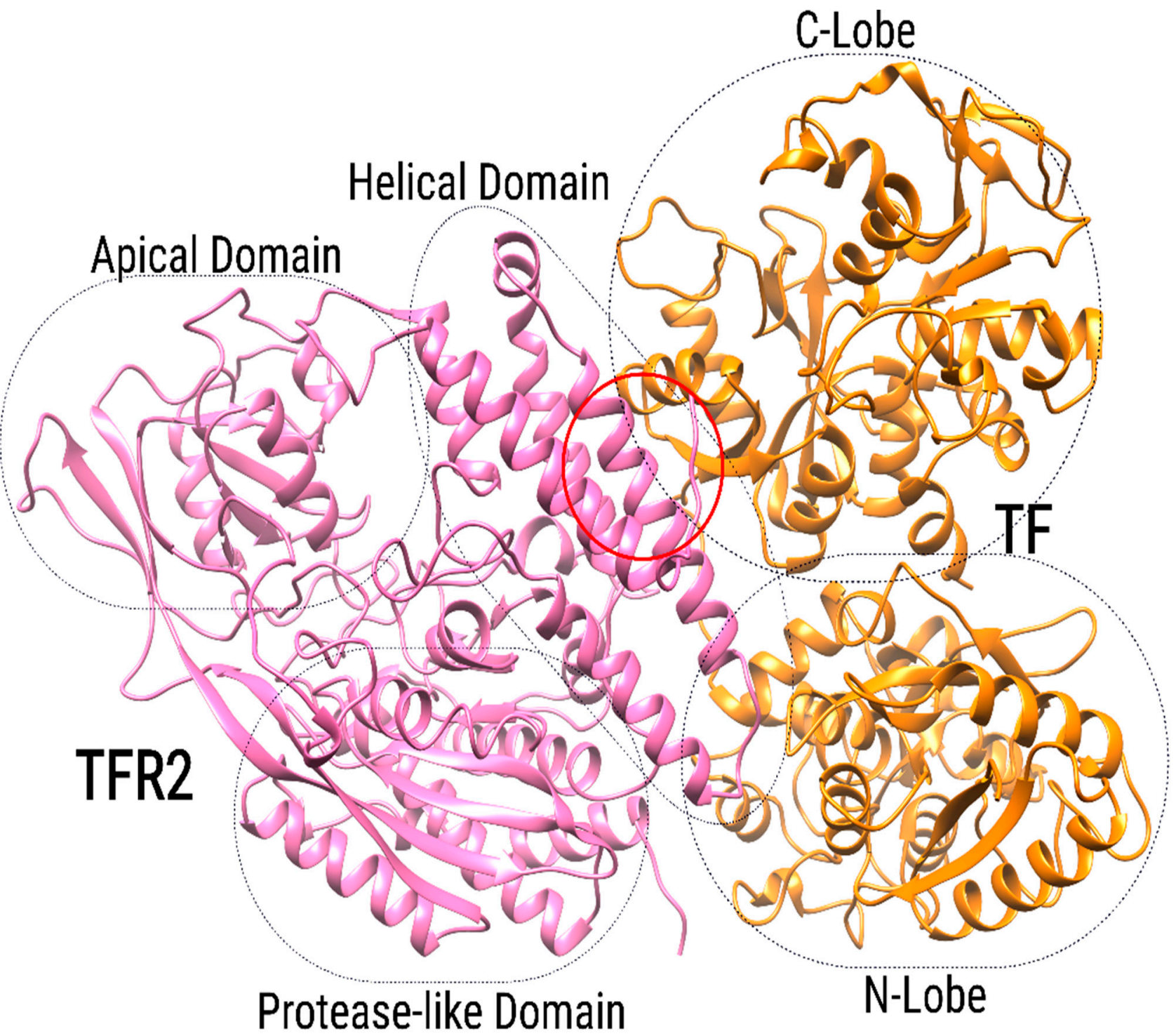

Figure A3. Global view of the binding mode between TFR2 (pink) and TF (orange) proteins. Black dots encircle all domains, and their corresponding names are indicated. The region where TFR2 position 680 is located is shown with a red circle.

\section{References}

1. Hentze, M.W.; Muckenthaler, M.U.; Galy, B.; Camaschella, C. Two to tango: Regulation of Mammalian iron metabolism. Cell 2010, 142, 24-38. [CrossRef]

2. Roetto, A.; Papanikolaou, G.; Politou, M.; Alberti, F.; Girelli, D.; Christakis, J.; Loukopoulos, D.; Camaschella, C. Mutant antimicrobial peptide hepcidin is associated with severe juvenile hemochromatosis. Nat. Genet. 2003, 33, 21-22. [CrossRef] [PubMed]

3. Kawabata, H.; Yang, R.; Hirama, T.; Vuong, P.T.; Kawano, S.; Gombart, A.F.; Koeffler, H.P. Molecular cloning of transferrin receptor 2. A new member of the transferrin receptor-like family. J. Biol. Chem. 1999, 274, 20826-20832. [CrossRef]

4. Nai, A.; Lidonnici, M.R.; Rausa, M.; Mandelli, G.; Pagani, A.; Silvestri, L.; Ferrari, G.; Camaschella, C. The second transferrin receptor regulates red blood cell production in mice. Blood 2015, 125, 1170-1179. [CrossRef]

5. Silvestri, L.; Nai, A.; Dulja, A.; Pagani, A. Hepcidin and the BMP-SMAD pathway: An unexpected liaison. Vitam. Horm. 2019, 110, 71-99.

6. $\quad$ Fleming, R.E.; Ahmann, J.R.; Migas, M.C.; Waheed, A.; Koeffler, H.P.; Kawabata, H.; Britton, R.S.; Bacon, B.R.; Sly, W.S. Targeted mutagenesis of the murine transferrin receptor-2 gene produces hemochromatosis. Proc. Natl. Acad. Sci. USA 2002, 99, 10653-10658. [CrossRef]

7. Wallace, D.F.; Summerville, L.; Lusby, P.E.; Subramaniam, V.N. First phenotypic description of transferrin receptor 2 knockout mouse, and the role of hepcidin. Gut 2005, 54, 980-986. [CrossRef] [PubMed] 
8. Wallace, D.F.; Summerville, L.; Subramaniam, V.N. Targeted disruption of the hepatic transferrin receptor 2 gene in mice leads to iron overload. Gastroenterology 2007, 132, 301-310. [CrossRef] [PubMed]

9. Bartnikas, T.B.; Wildt, S.J.; Wineinger, A.E.; Schmitz-Abe, K.; Markianos, K.; Cooper, D.M.; Fleming, M.D. A novel rat model of hereditary hemochromatosis due to a mutation in transferrin receptor 2. Comp. Med. 2013, 63, 143-155. [CrossRef] [PubMed]

10. Wang, R.H.; Li, C.; Xu, X.; Zheng, Y.; Xiao, C.; Zerfas, P.; Cooperman, S.; Eckhaus, M.; Rouault, T.; Mishra, L.; et al. A role of SMAD4 in iron metabolism through the positive regulation of hepcidin expression. Cell Metab. 2005, 2, 399-409. [CrossRef]

11. Meynard, D.; Kautz, L.; Darnaud, V.; Canonne-Hergaux, F.; Coppin, H.; Roth, M.P. Lack of the bone morphogenetic protein BMP6 induces massive iron overload. Nat. Genet. 2009, 41, 478-481. [CrossRef]

12. Muckenthaler, M.U.; Rivella, S.; Hentze, M.W.; Galy, B. A Red Carpet for Iron Metabolism. Cell 2017, 168, 344-361. [CrossRef]

13. Pietrangelo, A. Hereditary hemochromatosis-A new look at an old disease. N. Engl. J. Med. 2004, 350, 2383-2397. [CrossRef]

14. Feder, J.N.; Gnirke, A.; Thomas, W.; Tsuchihashi, Z.; Ruddy, D.A.; Basava, A.; Dormishian, F.; Domingo, R.; Ellis, M.C., Jr.; Fullan, A.; et al. A novel MHC class I-like gene is mutated in patients with hereditary haemochromatosis. Nat. Genet. 1996, 13, 399-408. [CrossRef]

15. Papanikolaou, G.; Samuels, M.E.; Ludwig, E.H.; MacDonald, M.L.; Franchini, P.L.; Dubé, M.P.; Andres, L.; MacFarlane, J.; Sakellaropoulos, N.; Politou, M.; et al. Mutations in HFE2 cause iron overload in chromosome 1q-linked juvenile hemochromatosis. Nat. Genet. 2004, 36, 77-82. [CrossRef]

16. Camaschella, C.; Roetto, A.; Calì, A.; De Gobbi, M.; Garozzo, G.; Carella, M.; Majorano, N.; Totaro, A.; Gasparini, P. The gene TFR2 is mutated in a new type of haemochromatosis mapping to 7q22. Nat. Genet. 2000, 25, 14-15. [CrossRef] [PubMed]

17. Pietrangelo, A.; Caleffi, A.; Henrion, J.; Ferrara, F.; Corradini, E.; Kulaksiz, H.; Stremmel, W.; Andreone, P.; Garuti, C. Juvenile hemochromatosis associated with pathogenic mutations of adult hemochromatosis genes. Gastroenterology 2005, 128, 470-479. [CrossRef] [PubMed]

18. Gérolami, V.; Le Gac, G.; Mercier, L.; Nezri, M.; Bergé-Lefranc, J.L.; Férec, C. Early-onset haemochromatosis caused by a novel combination of TFR2 mutations(p.R396X/c.1538-2 A>G) in a woman of Italian descent. Haematologica 2008, 93, e45-e46. [CrossRef]

19. Bardou-Jacquet, E.; Cunat, S.; Beaumont-Epinette, M.P.; Kannengiesser, C.; Causse, X.; Sauvion, S.; Pouliquen, B.; Deugnier, Y.; David, V.; Loréal, O.; et al. Variable age of onset and clinical severity in transferrin receptor 2 related haemochromatosis: Novel observations. Br. J. Haematol. 2013, 162, 278-281. [CrossRef] [PubMed]

20. Détivaud, L.; Island, M.L.; Jouanolle, A.M.; Ropert, M.; Bardou-Jacquet, E.; Le Lan, C.; Mosser, A.; Leroyer, P.; Deugnier, Y.; David, V.; et al. Ferroportin diseases: Functional studies, a link between genetic and clinical phenotype. Hum. Mutat. 2013, 34, 1529-1536. [CrossRef] [PubMed]

21. Girelli, D.; Busti, F.; Brissot, P.; Cabantchik, I.; Muckenthaler, M.U.; Porto, G. Hemochromatosis classification: Update and recommendations by the BIOIRON Society. Blood 2021. [CrossRef]

22. Takami, A.; Tatsumi, Y.; Sakai, K.; Toki, Y.; Ikuta, K.; Oohigashi, Y.; Takagi, J.; Kato, K.; Takami, K. Juvenile Hemochromatosis: A Case Report and Review of the Literature. Pharmaceuticals 2020, 13, 195. [CrossRef] [PubMed]

23. Alqanatish, J.; Alsowailmi, B.; Alfarhan, H.; Alhamzah, A.; Alharbi, T. Juvenile Hemochromatosis: Rheumatic Manifestations of 2 Sisters Responding to Deferasirox Treatment. A Case Series and Literature Review. Open Access Rheumatol. Res. Rev. 2021, 13, 15. [CrossRef] [PubMed]

24. Joshi, R.; Shvartsman, M.; Morán, E.; Lois, S.; Aranda, J.; Barqué, A.; de la Cruz, X.; Bruguera, M.; Vagace, J.M.; Gervasini, G.; et al. Functional consequences of transferrin receptor-2 mutations causing hereditary hemochromatosis type 3. Mol. Genet. Genom. Med. 2015, 3, 221-232. [CrossRef]

25. Khayat, A.A.; Suchi, M.; Vitola, B. A Rare Case Of a 2-year-old Boy with Alagille Syndrome and Type 3 Hereditary Hemochromatosis with TFR2 Mutation. J. Pediatric Gastroenterol. Nutr. 2019, 68, e68-e70. [CrossRef] [PubMed]

26. Wallace, D.F.; Summerville, L.; Crampton, E.M.; Subramaniam, V.N. Defective trafficking and localization of mutated transferrin receptor 2: Implications for type 3 hereditary hemochromatosis. Am. J. Physiol. Cell Physiol. 2008, 294, C383-C390. [CrossRef]

27. Galimberti, S.; Trombini, P.; Bernasconi, D.P.; Redaelli, I.; Pelucchi, S.; Bovo, G.; Di Gennaro, F.; Zucchini, N.; Paruccini, N.; Piperno, A. Simultaneous liver iron and fat measures by magnetic resonance imaging in patients with hyperferritinemia. Scand. J. Gastroenterol. 2015, 50, 429-438. [CrossRef]

28. Wood, J.C.; Enriquez, C.; Ghugre, N.; Otto-Duessel, M.; Aguilar, M.; Nelson, M.D.; Moats, R.; Coates, T.D. Physiology and pathophysiology of iron cardiomyopathy in thalassemia. Ann. N. Y. Acad. Sci. 2005, 1054, 386. [CrossRef]

29. Anderson, L.J.; Holden, S.; Davis, B.; Prescott, E.; Charrier, C.C.; Bunce, N.H.; Firmin, D.N.; Wonke, B.; Porter, J.; Walker, J.M.; et al. Cardiovascular T2-star (T2*) magnetic resonance for the early diagnosis of myocardial iron overload. Eur. Heart J. 2001, 22, 2171-2179. [CrossRef]

30. Mariani, R.; Pelucchi, S.; Perseghin, P.; Corengia, C.; Piperno, A. Erythrocytapheresis plus erythropoietin: An alternative therapy for selected patients with hemochromatosis and severe organ damage. Haematologica 2005, 90, 717-718.

31. Vila Cuenca, M.; Marchi, G.; Barqué, A.; Esteban-Jurado, C.; Marchetto, A.; Giorgetti, A.; Chelban, V.; Houlden, H.; Wood, N.W.; Piubelli, C.; et al. Genetic and Clinical Heterogeneity in Thirteen New Cases with Aceruloplasminemia. Atypical Anemia as a Clue for an Early Diagnosis. Int. J. Mol. Sci. 2020, 21, 2374. [CrossRef]

32. Kopanos, C.; Tsiolkas, V.; Kouris, A.; Chapple, C.E.; Albarca Aguilera, M.; Meyer, R.; Massouras, A. VarSome: The human genomic variant search engine. Bioinformatics 2019, 35, 1978. [CrossRef] [PubMed] 
33. Webb, B.; Andrej, S. Comparative Protein Structure Modeling Using MODELLER. Curr. Protoc. Protein Sci. 2016, 86, 5.6.1-5.6.30. [CrossRef] [PubMed]

34. Leaver-Fay, A.; Tyka, M.; Lewis, S.M.; Lange, O.F.; Thompson, J.; Jacak, R.; Kaufman, K.; Renfrew, P.D.; Smith, C.A.; Sheffler, W.; et al. ROSETTA3: An object-oriented software suite for the simulation and design of macromolecules. Methods Enzymol. 2011, 487, 545-574. [PubMed]

35. Sayers, E.W.; Bolton, E.E.; Brister, J.R.; Canese, K.; Chan, J.; Comeau, D.C.; Connor, R.; Funk, K.; Kelly, C.; Kim, S.; et al. Database resources of the National Center for Biotechnology Information. Nucleic Acids Res. 2021, 49, D13-D21. [CrossRef] [PubMed]

36. Li, W.; Godzik, A. Cd-hit: A fast program for clustering and comparing large sets of protein or nucleotide sequences. Bioinformatics 2006, 22, 1658-1659. [CrossRef]

37. Katoh, K.; Standley, D.M. MAFFT multiple sequence alignment software version 7: Improvements in performance and usability. Mol. Biol. Evol. 2013, 30, 772-780. [CrossRef] [PubMed]

38. Shannon, P.; Markiel, A.; Ozier, O.; Baliga, N.S.; Wang, J.T.; Ramage, D.; Amin, N.; Schwikowski, B.; Ideker, T. Cytoscape: A software environment for integrated models of biomolecular interaction networks. Genome Res. 2003, 13, 2498-2504. [CrossRef]

39. Cheng, Y.; Zak, O.; Aisen, P.; Harrison, S.C.; Walz, T. Structure of the human transferrin receptor-transferrin complex. Cell 2004, 116, 565-576. [CrossRef]

40. Robert, X.; Gouet, P. Deciphering key features in protein structures with the new ENDscript server. Nucleic Acids Res. 2014, 42, W320-W324. [CrossRef] [PubMed]

41. Alford, R.F.; Leaver-Fay, A.; Jeliazkov, J.R.; O’Meara, M.J.; DiMaio, F.P.; Park, H.; Shapovalov, M.V.; Renfrew, P.D.; Mulligan, V.K.; Kappel, K.; et al. The Rosetta All-Atom Energy Function for Macromolecular Modeling and Design. J. Chem. Theory Comput. 2017, 13, 3031-3048. [CrossRef]

42. Dubljevic, V.; Sali, A.; Goding, J.W. A conserved RGD (Arg-Gly-Asp) motif in the transferrin receptor is required for binding to transferrin. Biochem. J. 1999, 341 Pt 1, 11. [CrossRef] [PubMed]

43. Atkinson, H.J.; Morris, J.H.; Ferrin, T.E.; Babbitt, P.C. Using sequence similarity networks for visualization of relationships across diverse protein superfamilies. PLoS ONE 2009, 4, e4345. [CrossRef] [PubMed] 